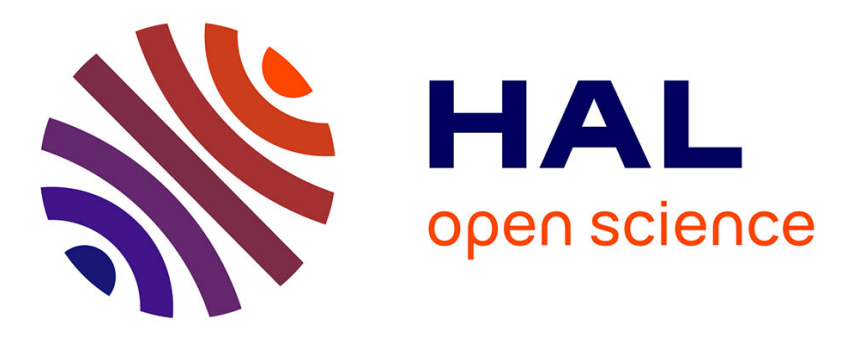

\title{
Individualization of textural and reactional microdomains in eclogites from the Bergen Arcs (Norway): Consequences for $\mathrm{Rb} / \mathrm{Sr}$ and $\mathrm{Ar} / \mathrm{Ar}$ radiochronometer behavior during polymetamorphism
}

Jodi Schneider, D. Bosch, P. Monié

\section{To cite this version:}

Jodi Schneider, D. Bosch, P. Monié. Individualization of textural and reactional microdomains in eclogites from the Bergen Arcs (Norway): Consequences for Rb/Sr and Ar/Ar radiochronometer behavior during polymetamorphism. Geochemistry, Geophysics, Geosystems, 2008, 9, pp.Q12001. 10.1029/2008GC002098 . hal-00407885

\section{HAL Id: hal-00407885 \\ https://hal.science/hal-00407885}

Submitted on 20 Dec 2021

HAL is a multi-disciplinary open access archive for the deposit and dissemination of scientific research documents, whether they are published or not. The documents may come from teaching and research institutions in France or abroad, or from public or private research centers.
L'archive ouverte pluridisciplinaire $\mathbf{H A L}$, est destinée au dépôt et à la diffusion de documents scientifiques de niveau recherche, publiés ou non, émanant des établissements d'enseignement et de recherche français ou étrangers, des laboratoires publics ou privés. 


\title{
Individualization of textural and reactional microdomains in eclogites from the Bergen Arcs (Norway): Consequences for $\mathrm{Rb} / \mathrm{Sr}$ and $\mathrm{Ar} / \mathrm{Ar}$ radiochronometer behavior during polymetamorphism
}

\author{
Julie Schneider \\ Géosciences Azur, Université Nice-Sophia Antipolis, UMR6526, 28 avenue Valrose, F-06108 Nice CEDEX 02, France \\ (julie.schneider@unice.fr) \\ Delphine Bosch and Patrick Monié \\ Géosciences Montpellier, Université Montpellier II, CNRS, UMR5243, Place E. Bataillon, F-34095 Montpellier \\ CEDEX 05, France (bosch@gm.univ-montp2.fr; monie@gm.univ-montp2.fr)
}

[1] $\mathrm{Rb} / \mathrm{Sr},{ }^{40} \mathrm{Ar} /{ }^{39} \mathrm{Ar}$, and $\mathrm{Sm} / \mathrm{Nd}$ isotopic data are reported in Caledonian eclogites from the Lindås Nappe, Bergen Arcs, Norway, in order to investigate processes controlling isotopic equilibrium at mineral scale in polymetamorphic rocks. The Bergen Arcs exposes Sveconorwegian 950-930 Ma granulites, partially overprinted by Caledonian eclogite-facies metamorphism at $\sim 425 \mathrm{Ma}$ and amphibolite-facies metamorphism at $\sim 410 \mathrm{Ma}$. Geochemical and $\mathrm{Rb}$-Sr data from more than 10 phengite fractions separated from one sample reflect the composition of the microdomain (a few hundred microns in size) in which phengite crystallized. Phengite crystallized after garnet or plagioclase by dissolution-precipitation processes yield apparent age between 700 and $600 \mathrm{Ma}$. At the time of their crystallization, these phengites inherited the isotopic composition of their precursor minerals, at a microdomain scale. Phengite from quartz veins, which crystallized from elements mobilized by the circulating fluid, yield an age closer to the eclogite-facies metamorphic age. The closed system evolution of the eclogitizing fluid, the segregation of textural and reactional microdomains, the high Sr content of the studied phengite, and the short duration of the recrystallization processes $(<1 \mathrm{Ma})$ are interpreted as the main factors responsible for the lack of a $\mathrm{Rb} / \mathrm{Sr}$ isotopic equilibrium, at the scale of hand samples. Such equilibrium is nevertheless reached in quartz veins where the crystallization of minerals implies that the fluid circulation acted as a factor of isotopic homogenization. The in situ single mineral Ar/Ar datings revealed that both eclogite- and amphibolitefacies minerals are characterized by an excess of radiogenic argon (ages between 425 and $520 \mathrm{Ma}$ ). The excess of argon has been inherited from the previous granulite and has been only partially evacuated from the system by the circulating fluid. The apparent $\mathrm{Sm} / \mathrm{Nd}$ ages from garnets inherited from the granulitefacies metamorphism (c. $930 \mathrm{Ma}$ ) are in agreement with previous estimates. This result confirms that the diffusion of $\mathrm{Nd}$ in garnet does not occur at temperatures lower than $700^{\circ} \mathrm{C}$. This study highlights the complexity of radiochronometer behavior during HP metamorphism and demonstrates that coupling different radiochronometers, such as $\mathrm{Ar} / \mathrm{Ar}$ and $\mathrm{Rb} / \mathrm{Sr}$, does not always guarantee the validity of the geochronological results.

Components: 14,708 words, 10 figures, 6 tables.

Keywords: $\mathrm{Rb} / \mathrm{Sr}, \mathrm{Ar} / \mathrm{Ar}, \mathrm{Sm} / \mathrm{Nd}$ geochronology; isotope equilibrium; microdomains; polymetamorphism; eclogite; fluid. 
Index Terms: 1115 Geochronology: Radioisotope geochronology.

Received 14 May 2008; Revised 9 September 2008; Accepted 1 October 2008; Published 2 December 2008.

Schneider, J., D. Bosch, and P. Monié (2008), Individualization of textural and reactional microdomains in eclogites from the Bergen Arcs (Norway): Consequences for $\mathrm{Rb} / \mathrm{Sr}$ and $\mathrm{Ar} / \mathrm{Ar}$ radiochronometer behavior during polymetamorphism, Geochem. Geophys. Geosyst., 9, Q12001, doi:10.1029/2008GC002098.

\section{Introduction}

[2] Determination of reliable pressure-temperaturetime $(\mathrm{P}, \mathrm{T}, \mathrm{t})$ paths for metamorphic events and derivation of credible tectonic models rely on correct understanding of the behavior of radiochronometers used to date metamorphism. One critical point is to determine how and when isotopic equilibrium is reached between metamorphic minerals. Two conditions have to be fulfilled to obtain reliable ages. First, the minerals under investigation, either inherited or neoformed, have to reach isotopic equilibrium at the time of closure of the isotopic system under consideration. Second, the subsequent variations of the isotopic composition should only be controlled by radioactive decay processes. Isotopic equilibrium depends on the efficiency of several parameters for the migration of isotopes, some of which are independent from the mineral s.s. (e.g., temperature, deformation, fluid, etc.) and others that are intrinsic to the mineral (e.g., chemical composition, lattice structure, etc.). In the case of inherited minerals (i.e., minerals which remain totally or partially stable in the new pressure-temperature conditions), the new isotopic equilibrium will be driven by volume diffusion, which is controlled, at the first order, by temperature. Volume diffusion, for a given mineral, is only effective above a limited temperature, called "closure temperature" [e.g., Dodson, 1973].

[3] Numerous studies have reported isotopic data in minerals difficult to interpret in terms of the classical closure temperature concept [e.g., Verschure et al., 1980; Santos Zalduegui et al., 1995; De Jong, 2003; Maurel et al., 2003]. In the case of newly formed minerals, the partial or complete breakdown of precursor minerals, combined with the physical opening of the system, should be accompanied by a resetting of the isotopic system. This process should promote element redistribution between the different phases of the system and the release of previously accumulated radiogenic isotopes, thus allowing for an isotopic equilibrium to be reached. However, several studies have reported ${ }^{40} \mathrm{Ar} /{ }^{39} \mathrm{Ar}$ ages of neoformed minerals with no geological significance [e.g., Dallmeyer et al., 1991; Arnaud and Kelley, 1995; Boundy et al., 1997a; Di Vincenzo et al., 2006]. These erroneous apparent ages are generally related to the excess of radiogenic argon trapped in the analyzed minerals. This excess of argon can be explained by an inheritance phenomenon [e.g., Foland, 1979; Sherlock and Kelley, 2002] or by fluid circulation after the crystallization of the minerals [e.g., De Jong et al., 2001]. Similarly, $\mathrm{Sm} / \mathrm{Nd}$ ages without geological significance [e.g., Cliff et al., 1998; Thöni, 2003], or even future ages [e.g., Jagoutz, 1995; Miller and Thöni, 1997], have also been reported for neoformed minerals. In most studies, this has been attributed to the occurrence of inherited microinclusions located in the crystalline lattice of the analyzed minerals [e.g., Zhou and Hensen, 1995; De Wolf et al., 1996; Scherer et al., 2000]. In other studies, it has been demonstrated that the isotopic disequilibrium was related to an inheritance from precursor minerals [e.g., Griffin and Brueckner, 1985; Mørk and Mearns, 1986; Jagoutz, 1995; Schmädicke et al., 1995]. In this case, the lack of active deformation and/or fluid circulation is often invoked to explain the incomplete reset of the system.

[4] Recrystallization, deformation, and fluid circulation are widely regarded as key processes to reach isotopic equilibrium during metamorphism. In this study, the influence of these processes is evaluated taking the example of the classical Bergen Arcs eclogites in western Norway [e.g., Austrheim, 1987]. In the Bergen Arcs, transformation of Grenvillian granulites into Caledonian eclogites is well exposed in the field and clearly associated with fluid circulation and deformation.

[5] A detailed $\mathrm{Rb} / \mathrm{Sr}, \mathrm{Sm} / \mathrm{Nd}$, and $\mathrm{Ar} / \mathrm{Ar}$ isotopic study was performed in minerals from two eclogite-facies samples. This isotopic study is based on previously published data concerning an extensive petrological and geochemical work realized on the same mineral fractions [Schneider et al., 2007]. Selected samples contained both 
inherited and neoformed minerals. The study shows that (1) different populations of neoformed minerals yield intermediate ages between the two main metamorphic events (i.e., granulite- and eclogite-facies) and therefore, do not provide the true age of the HP event, (2) different populations of a single mineral species are not in isotopic equilibrium, (3) these different populations inherited their isotopic compositions from precursor minerals located in specific and distinct textural microdomains, (4) isotopic exchanges are limited to a few hundred microns.

\section{Geological and Geochronological Background}

[6] The analyzed eclogites were collected on the Holsnøy Island in the Lindås Nappe (Figure 1). The Lindås Nappe is part of the Bergen Arc system in western Norway and mainly consists of a Proterozoic anorthositic complex. The anorthosite suite ranges from pure anorthosite to anorthositic gabbro and is locally intruded by jotunite and mangerite dated at around 957-945 Ma [Austrheim, 1990; Bingen et al., 2001]. The Lindås Nappe underwent a first granulite-facies metamorphic overprint during the Sveconorwegian orogeny $\left(0.8-1.1 \mathrm{GPa}, 780-900^{\circ} \mathrm{C}\right)$ [Austrheim and Griffin, 1985; Kühn, 2002] and a second metamorphic/deformation event during the Caledonian orogeny. The Caledonian metamorphism, related to the subduction of the Baltica margin beneath the Laurentian plate, took place in the eclogite facies $\left(1.8\right.$ to $\left.2.1 \mathrm{GPa}, \sim 700-750^{\circ} \mathrm{C}\right)$ [Jamtveit et al., 1990; Raimbourg et al., 2007] and was followed by a retrogression in the amphibolite facies (1 to $1.2 \mathrm{GPa}, 650-690^{\circ} \mathrm{C}$ ) [Boundy et al., 1996; Kühn, 2002]. The eclogitization is mainly controlled by deformation and fluid circulation. Dry granulites remain metastable in the eclogite facies until brittle fracturing allows fluid percolation, leading to metamorphic reactions and ductile deformation [e.g., Austrheim, 1987; Boundy et al., 1992]. More than $70 \%$ of the granulites are preserved and the eclogites and/or amphibolites are only found in shear zones or as reaction front around fractures, with both acting as fluid pathways.

[7] U-Pb dating on zircons yielded an age of $\sim 930-925 \mathrm{Ma}$ for the granulite-facies metamorphism [Bingen et al., 2001]. Burton et al. [1995] calculated a cooling rate of $4^{\circ} \mathrm{C} / \mathrm{Ma}$ for the postgranulitization cooling in the Lindås Nappe. The phlogopite $\mathrm{Rb} / \mathrm{Sr}$ ages, from granulitized lherzolites and websterites, range from $882 \pm 9$ to $835 \pm$
7 Ma [Kühn et al., 2000]. For the eclogite-facies metamorphism, the $\mathrm{U} / \mathrm{Pb}, \mathrm{Sm} / \mathrm{Nd}$, and $\mathrm{Rb} / \mathrm{Sr}$ datings give consistent ages around $\sim 425 \mathrm{Ma}$ [Bingen et al., 2001, 2004; Kühn et al., 2002; Glodny et al., 2008]. The Ar/Ar ages of phengite from eclogites range from $\sim 429$ to $\sim 548 \mathrm{Ma}$ [Boundy et al., 1996, 1997a, 1997b]. The age dispersion is interpreted as a heterogeneous incorporation of ${ }^{40} \mathrm{Ar}$ excess transported by fluids during the crystallization of eclogite-facies minerals [Boundy et al., 1997a]. The age of the retrograde amphibolite-facies metamorphism is constrained between $\sim 408 \mathrm{Ma}$ and $\sim 414 \mathrm{Ma}$ by $\mathrm{Rb} / \mathrm{Sr}$ ages on minerals from amphibolite shear zones and veins [e.g., Austrheim, 1990; Bingen et al., 2001; Glodny et al., 2008].

\section{Sample Description}

[8] A detailed petrographic and geochemical (major and trace elements) description and discussion of the samples studied has been previously published in Schneider et al. [2007] and is only briefly summarized here and in Table 1. Sample NOK10a was collected from the edge of a granulite boudin that is eclogitized at the rim. It has a modal composition that is dominated by garnet, epidote, and kyanite and is phengite-poor (i.e., a Ky-rich eclogite). Sample NOK10d was collected at the core of an eclogite shear zone. The modal composition of this eclogite is kyanite-free and the assemblage is dominated by garnet, omphacite, phengite, and epidote ( $\mathrm{Ph}$-rich eclogite). Both samples were mostly equilibrated in the eclogite facies and only partially retrogressed in the amphibolite facies (Caledonian metamorphism), but minerals inherited from the granulite facies Grenvillian metamorphism are still present (Table 1). The main eclogite-facies reactions can be summarized as follow:

$$
\begin{gathered}
\mathrm{Pl}+\mathrm{H}_{2} \mathrm{O}=\mathrm{Ep}+\mathrm{Ph}+\mathrm{Qtz} \pm \mathrm{Ky} \\
\mathrm{Grt} 1+\mathrm{Pl}+\mathrm{H}_{2} \mathrm{O}=\mathrm{Omp}+\mathrm{Ph}+\mathrm{Ky}
\end{gathered}
$$

$$
\mathrm{Di}+\mathrm{Grt} 1+\mathrm{Fe}-\mathrm{Ti} \text { oxides }=\mathrm{Omp}+\mathrm{Grt} 2+\mathrm{Rt}
$$

Reaction (1) is observed in both samples, reactions (2) and (3) are only observed in sample NOK10a, and reaction (4) was only seen in sample NOK10d. 


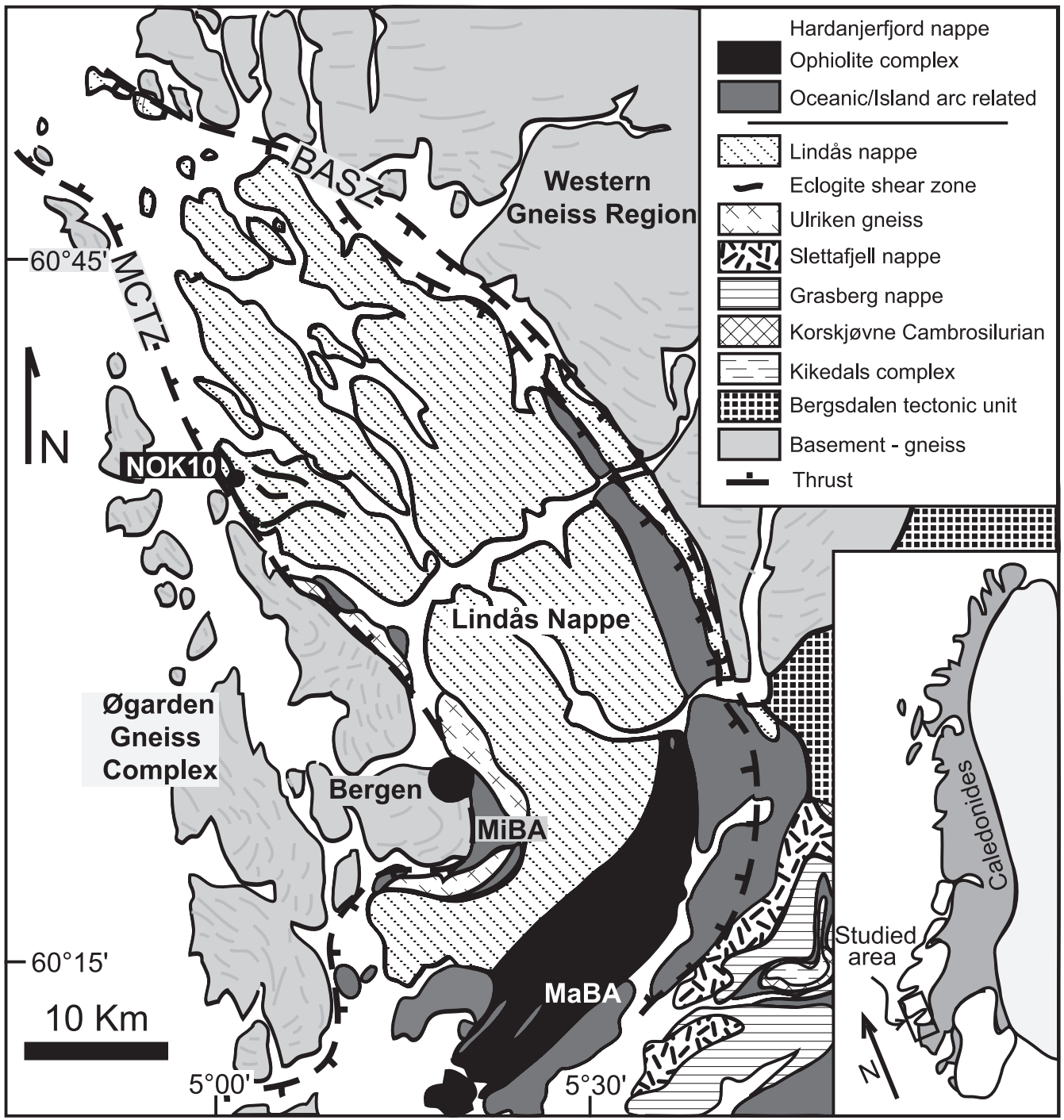

Figure 1. Geological map of the Bergen Arcs area with location of the sampling site (NOK10). Modified after Boundy et al. [1996] and Bingen et al. [2001].

The $\mathrm{K}$ amount contained in the crystallized phengite arises from exsolution microtextures of $\mathrm{K}$-feldspar antiperthitic grains located in the crystalline lattice of the granulite-facies plagioclase [Austrheim, 1990]. The Fe-Mg component of phengite comes from the local breakdown of granulite-facies diopside in omphacite.

[9] Both samples are made of several distinct textural domains characterized by specific mineralogical reactions. Therefore, a given mineral species can be found in different reactional microdomains. In sample NOK10a, eclogite-facies phengite is found in three distinct textural domains: (1) the main foliation associated with epidote as a result of a plagioclase breakdown (reaction (1); Figure 2a), (2) garnet pressure shadows as a result of garnet breakdown (reaction (2); Figure 2b), and (3) quartz lenses directly precipitated from the circulating fluid (Figure 2c). In sample NOK10d, phengite primarily occurs in the main foliation (Figure 2d) as a result of plagioclase breakdown (reaction (1)). Extensive chemical analyses of the phengite populations revealed that the different groups of phengite have specific chemical features related to their peculiar crystallization process [Schneider et al., 2007].

\section{Analytical Techniques}

[10] Several fractions (up to 13 for phengite) of a given mineral species have been separated on the basis of grain size, density, and magnetic suscep- 
tibility (Tables 2 and 3). Previous trace elements analyses done on aliquots from the same fractions [Schneider et al., 2007] have revealed that these different phengite fractions are related to distinct mineralogical reactions represented in the samples by specific textural sites (microdomains).

\section{1. $\mathrm{Rb} / \mathrm{Sr}$ and $\mathrm{Sm} / \mathrm{Nd}$ Analyses}

[11] Separated minerals were first washed with acetone and then with distilled water before grinding in an agate mortar. Some whole-rock (WR) and garnet fractions were treated with acid leaching before the analyses. Acid leaching was also performed on aliquots of phengite fractions. The trace elements analyses of leachates are provided in auxiliary material. ${ }^{1}$ The leaching consisted of a 30 min bath in $2.5 \mathrm{~N} \mathrm{HCl}$ at $120^{\circ} \mathrm{C}$ followed by a second step in $6 \mathrm{~N} \mathrm{HCl}$ for WR. Solid residues were then rinsed three times with distilled $\mathrm{H}_{2} \mathrm{O}$ to remove chlorines. Garnet fractions were oxidized in concentrated $\mathrm{HNO}_{3}$ at $180^{\circ} \mathrm{C}$ overnight to facilitate the digestion. The sample dissolution was done with a $2: 1$ mixture of $\mathrm{HF}(48 \%)$ and $\mathrm{HNO}_{3}$ $(13 \mathrm{~N})$ at $160^{\circ} \mathrm{C}$ for a period of 1 to 2 weeks. During the subsequent evaporation, $0.1 \mathrm{cc}$ of $\mathrm{HClO}_{4}$ was added (except for the phengite) just before total dryness in order to avoid the formation of insoluble fluorine complexes. The dry residue was then treated with $6 \mathrm{~N} \mathrm{HCl}$ for $1 \mathrm{~h}$ at $120^{\circ} \mathrm{C}$ in order to complex the REE before chemically separating the elements. After total dissolution, an aliquot of each fraction has been used to measure element concentration by ICP-MS [Schneider et $a l ., 2007]$. This allowed us to precisely spike the samples at this stage. The total blanks were below $173 \mathrm{pg}$ for $\mathrm{Sr}, 5 \mathrm{pg}$ for $\mathrm{Rb}, 8 \mathrm{pg}$ for $\mathrm{Nd}$, and $0.6 \mathrm{pg}$ for $\mathrm{Sm}$.

[12] The ${ }^{87} \mathrm{Sr} /{ }^{86} \mathrm{Sr}$ and ${ }^{84} \mathrm{Sr} /{ }^{86} \mathrm{Sr}$ ratios were measured on a Finnigan Mat 262 mass spectrometer housed at the Paul Sabatier University (Toulouse). Repeated ${ }^{87} \mathrm{Sr} /{ }^{86} \mathrm{Sr}$ ratio measurements of the NBS 987 standard during the course of this study yielded an average of $0.710252 \pm 0.0000010(\mathrm{n}=$ $15 ; 2 \sigma)$. The ${ }^{143} \mathrm{Nd} /{ }^{144} \mathrm{Nd}$ ratios were measured on a MC-ICP-MS VG P54 at the ENS Lyon following the procedure described by Luais et al. [1997]. The ${ }^{143} \mathrm{Nd} /{ }^{144} \mathrm{Nd}$ ratios of the Lyon "in-house" standards yielded an average of $0.512134 \pm 0.000024(\mathrm{n}=102$; 2 $\sigma$ ). The ${ }^{87} \mathrm{Rb} /{ }^{85} \mathrm{Rb},{ }^{146} \mathrm{Nd} /{ }^{145} \mathrm{Nd}$ and ${ }^{149} \mathrm{Sm} /{ }^{147} \mathrm{Sm}$ ratios were measured by conventional nebulization ICP-MS using a VG Plasmaquad 2 at ISTEEM,

${ }^{1}$ Auxiliary materials are available in the HTML. doi:10.1029/ 2008GC002098. 

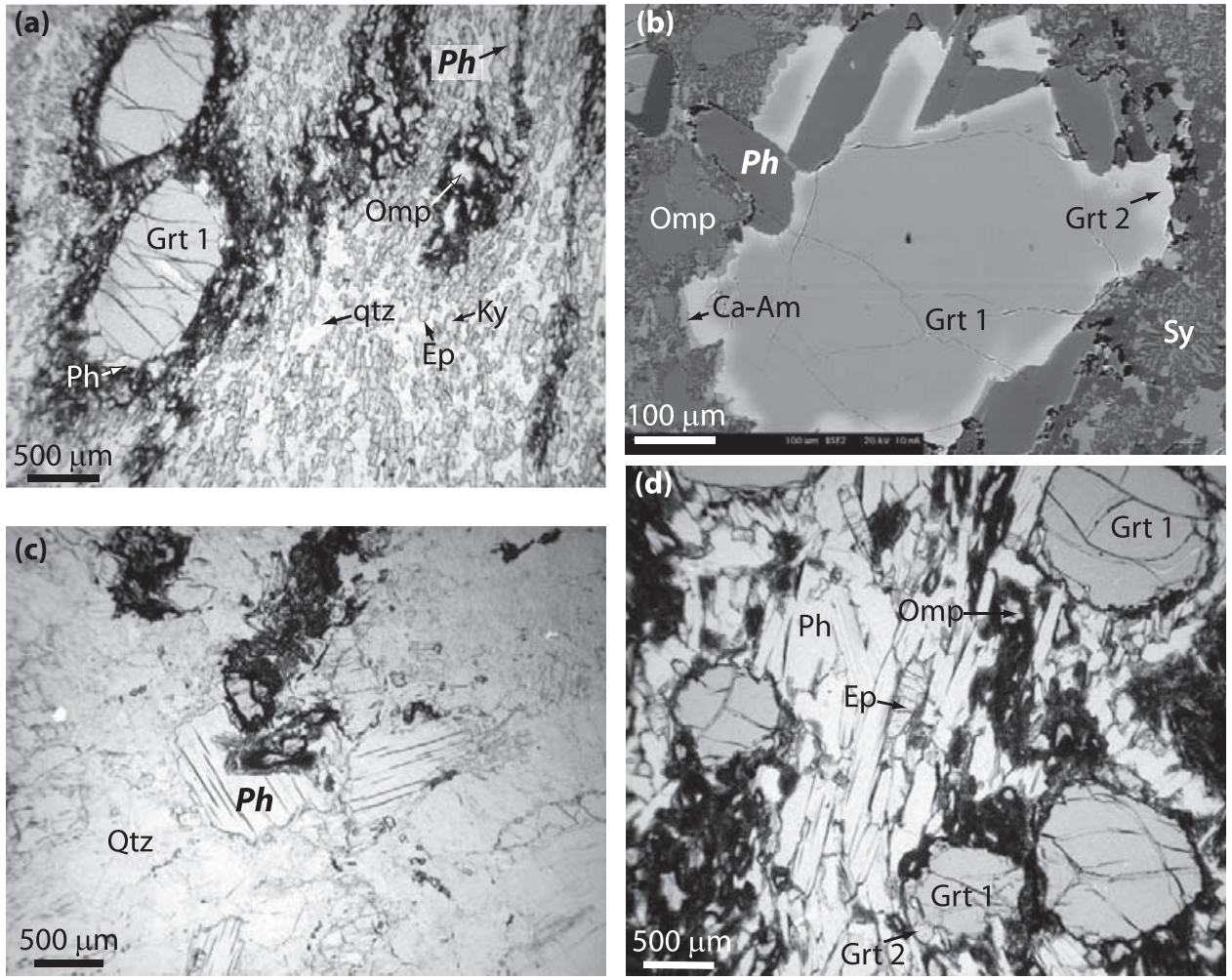

Figure 2. The $30 \mu \mathrm{m}$-thick section photomicrographs of eclogite in natural light (NL) and backscattered electron (BSE) showing the different textural location of phengite. (a) Phengite replacing plagioclase in NOK10a (mode NL). Phengite is located in the main foliation and is associated with Ep, Qtz, and Ky. (b) Phengite replacing garnet in NOK10a (BSE mode). Note the pseudomorphic-like replacement of garnet by phengite and the two generations of garnet with the granulite-facies garnet (Grt 1, darker core) and the eclogite-facies garnet (Grt 2, thin lighter rim). (c) Phengite precipitating after fluid in NOK10a (mode NL). This type of phengite is essentially found in quartz lenses located at the edge of coronite. (d) Phengite replacing plagioclase in NOK10d (mode NL). Phengite is abundant in this sample and is associated with Ep and Qtz. Abbreviations are after Kretz [1983] except for phengite $(\mathrm{Ph})$, symplectite (Sy), and calcic-amphibole (Ca-Am).

Montpellier II University with a precision for all of the ratios between \pm 0.5 and $1 \%(1 \sigma \mathrm{RSD})$. The blank contribution to the $\mathrm{Rb}$ and $\mathrm{Sr}$ signal for phengite was below $0.001 \%$ and $0.002 \%$, respectively, and the blank contribution for $\mathrm{Nd}$ was below $0.01 \%$ for garnets. Isochrons were calculated using the ISOPLOT program [Ludwig, 2001]. All of the $\mathrm{Rb}, \mathrm{Sr}, \mathrm{Sm}$, and $\mathrm{Nd}$ concentrations obtained by isotopic dilution (Tables 2, 3, and 4) agree with the values obtained by the ICP-MS for the same fractions [Schneider et al., 2007].

\subsection{Ar/Ar Dating Procedure}

[13] Ar/Ar step heating experiments were conducted on phengite grains between 250 and $400 \mu \mathrm{m}$ in size (i.e., the same fractions as those used for the $\mathrm{Rb} / \mathrm{Sr}$ and trace elements analyses). The total fusion analysis was conducted on smaller grains $(150 \mu \mathrm{m})$, and the in situ laser ablation analyses were carried out on one large grain (over $500 \mu \mathrm{m}$ ) for sample NOK10a, and on polished thick sections (phengite and amphibole) for sample NOK10d. Details on the whole procedure have been already described by Schneider et al. [2004]. The quoted errors are listed at $1 \sigma$ and were calculated after McDougall and Harrison [1988]. The errors on the ages are approximately 4 to $4.5 \mathrm{Ma}$, which corresponds to less than a $1 \%$ error on the calculated age, with the exception of one grain in sample NOK10d, where the error is over $10 \mathrm{Ma}$ (2\%) (Tables 5 and 6). The flux monitor used during this study is MMHb-1 with an age of $520.4 \pm 1.7 \mathrm{Ma}$ [Samson and Alexander, 1987]. The J uncertainty ranges from 0.5 to $1 \%$ and is propagated in the calculation of plateau age and total gas age errors.

\subsection{X-Ray Diffraction Procedure}

[14] Four powdered phengite fractions from sample NOK10a were analyzed by X-ray diffraction in 
Table 2. $\mathrm{Rb} / \mathrm{Sr}$ Results for Various Minerals From Sample NOK10a (Ky-Rich Eclogite) ${ }^{\mathrm{a}}$

\begin{tabular}{|c|c|c|c|c|c|c|c|c|c|c|}
\hline & \multirow[b]{2}{*}{$\begin{array}{l}\text { Grain Size } \\
\quad(\mathrm{mm})\end{array}$} & \multirow[b]{2}{*}{ Density } & \multicolumn{3}{|c|}{$\begin{array}{l}\text { Frantz Isodynamic } \\
\text { Parameters }\end{array}$} & \multicolumn{2}{|c|}{$\begin{array}{r}\text { Concentration } \\
(\mathrm{ppm}), \pm 2 \%\end{array}$} & \multicolumn{3}{|c|}{$\begin{array}{l}\text { Isotopic Ratio } \\
2 \sigma \text { Error }\end{array}$} \\
\hline & & & $\begin{array}{l}\text { Counter } \\
\text { Slope }\end{array}$ & $\begin{array}{l}\text { Intensity } \\
\text { (A) }\end{array}$ & Attraction & $\mathrm{Sr}$ & $\mathrm{Rb}$ & ${ }^{87} \mathrm{Sr} /{ }^{86} \mathrm{Sr}$ & ${ }^{87} \mathrm{Rb}$ & ${ }^{86} \mathrm{Sr}$ \\
\hline \multicolumn{11}{|c|}{ Phengite } \\
\hline $2+a$ & $125-250$ & $2.9<-<3.3$ & $10^{\circ}$ & Max & unattracted & 891 & 17.6 & $0.703344 \pm 8$ & 0.0571 & 0.0019 \\
\hline $2+\mathrm{b}$ & $125-250$ & $2.9<-<3.3$ & $10^{\circ}$ & Max & attracted & 920 & 16.3 & $0.703306 \pm 8$ & 0.0513 & 0.0016 \\
\hline $2+\mathrm{c}$ & $125-250$ & $2.9<-<3.3$ & - & - & - & 1174 & 22.2 & $0.703325 \pm 8$ & 0.0548 & 0.0054 \\
\hline $1+\mathrm{a}$ & $100-125$ & $2.9<-<3.3$ & $5^{\circ}$ & Max & unattracted & 867 & 15.7 & $0.703300 \pm 10$ & 0.0510 & 0.0020 \\
\hline $1+b$ & $100-125$ & $2.9<-<3.3$ & $15^{\circ}$ & 1.3 & unattracted & 1179 & 15.6 & $0.703210 \pm 7$ & 0.0384 & 0.0012 \\
\hline $4-\mathrm{a}$ & $250-400$ & $<2.9$ & $12.5^{\circ}$ & Max & attracted & 899 & 17.4 & $0.703358 \pm 7$ & 0.0560 & 0.0024 \\
\hline $4-b$ & $250-400$ & $<2.9$ & $2.5^{\circ}$ & Max & unattracted & 926 & 16.9 & $0.703316 \pm 9$ & 0.0529 & 0.0020 \\
\hline $4-c$ & $250-400$ & $<2.9$ & $2.5^{\circ}$ & Max & attracted & 1082 & 18.8 & $0.703306 \pm 8$ & 0.0502 & 0.0035 \\
\hline $2-a$ & $125-250$ & $<2.9$ & $5^{\circ}$ & Max & attracted & 873 & 17.8 & $0.703389 \pm 9$ & 0.0590 & 0.0015 \\
\hline 2-are & $125-250$ & $<2.9$ & $5^{\circ}$ & Max & attracted & 845 & 17.1 & $0.703382 \pm 10$ & 0.0586 & 0.0020 \\
\hline $2-b$ & $125-250$ & $<2.9$ & $5^{\circ}$ & Max & unattracted & 968 & 17.7 & $0.703329 \pm 8$ & 0.0529 & 0.0015 \\
\hline $2-c$ & $125-250$ & $<2.9$ & - & - & - & 920 & 17.1 & $0.703338 \pm 8$ & 0.0539 & 0.0018 \\
\hline $1-\mathrm{a}$ & $100-125$ & $<2.9$ & $10^{\circ}$ & Max & attracted & 765 & 17.6 & $0.703404 \pm 7$ & 0.0666 & 0.0021 \\
\hline $1-b$ & $100-125$ & $<2.9$ & $5^{\circ}$ & Max & attracted & 984 & 16.9 & $0.703321 \pm 7$ & 0.0496 & 0.0014 \\
\hline \multicolumn{11}{|c|}{ Garnet } \\
\hline $\mathrm{A}^{\prime}$ & $250-400$ & $>3.3$ & $15^{\circ}$ & 0.55 & unattracted & 4.54 & 0.044 & $0.703173 \pm 15$ & 0.0262 & 0.0008 \\
\hline $\mathrm{C}$ & $250-400$ & $>3.3$ & $15^{\circ}$ & 0.525 & unattracted & 3.13 & 0.063 & $0.703170 \pm 7$ & 0.0542 & 0.0021 \\
\hline $\mathrm{D}$ & $250-400$ & $>3.3$ & $15^{\circ}$ & 0.525 & attracted & 2.46 & 0.044 & $0.703222 \pm 8$ & 0.0483 & 0.0004 \\
\hline $\mathrm{E}$ & $250-400$ & $>3.3$ & $15^{\circ}$ & 0.5 & attracted & 3.87 & 0.041 & $0.703181 \pm 10$ & 0.0285 & 0.0003 \\
\hline \multicolumn{11}{|c|}{ Epidote } \\
\hline & $100-125$ & $>3.3$ & $10^{\circ}$ & Max & attracted & 5510 & 0.087 & $0.702976 \pm 7$ & 0.00005 & 0.00001 \\
\hline \multicolumn{11}{|c|}{ Mixed Fraction Epidote-Kyanite } \\
\hline & $100-125$ & $>3.3$ & $2.5^{\circ}$ & Max & attracted & 1043 & 0.225 & $0.702978 \pm 8$ & 0.00062 & 0.00128 \\
\hline \multicolumn{11}{|c|}{ Kyanite } \\
\hline & $100-125$ & $>3.3$ & $0^{\circ}$ & Max & unattracted & 78 & 0.062 & $0.703010 \pm 8$ & 0.00230 & 0.00012 \\
\hline \multicolumn{11}{|c|}{ Whole Rock } \\
\hline Unleached & & & & & & 881 & 0.878 & $0.702980 \pm 8$ & 0.00264 & 0.00017 \\
\hline $\begin{array}{l}\text { Leached } \\
\qquad \mathrm{HCl} 2.5 \mathrm{~N}\end{array}$ & & & & & & 893 & 0.489 & $0.702971 \pm 9$ & 0.00138 & 0.00010 \\
\hline $\begin{array}{r}\text { Leached } \mathrm{HCl} \\
2.5 \mathrm{~N}+6 \mathrm{~N}\end{array}$ & & & & & & 662 & 0.453 & $0.702959 \pm 7$ & 0.00097 & 0.00007 \\
\hline
\end{tabular}

\footnotetext{
${ }^{\mathrm{a}}$ The details of grain size, density, and magnetism used to separate the different mineral fractions are indicated.
}

order to test the occurrence of undetected phases in the interlamellar space of the phengite grains. The X-ray diffraction measurements on dried phengite powders were carried out in $1 \mathrm{~mm}$ diameter glass capillaries, in the Laboratoire des Colloïdes, Verres et Nanomatériaux, at Montpellier II University. Work was done in a transmission configuration. A copper rotating anode X-ray source (functioning at $4 \mathrm{~kW}$ ) with a multilayer focusing "Osmic" monochromator giving high flux $\left(10^{8}\right.$ photons $\left./ \mathrm{sec}\right)$ and punctual collimation was used as well as an "Image plate" 2-D detector was used. X-ray diagrams were obtained, which showed the scattered intensity as a function of the wave vector q. The analytical results are available in auxiliary material.

\section{Results}

\section{1. $\mathrm{Rb} / \mathrm{Sr}$ Isotope Systematics}

[15] Thirteen phengite fractions were analyzed in sample NOK10a and eight in sample NOK10d, plus duplicates (labeled "re," Tables 2 and 3). Together with phengite, four garnet fractions, one epidote fraction, one kyanite fraction, and a mixed fraction of kyanite and epidote were analyzed for sample NOK10a. In sample NOK10d, three garnet 
Table 3. $\mathrm{Rb} / \mathrm{Sr}$ Results for Various Minerals From Sample NOK10d (Ph-Rich Eclogite)

\begin{tabular}{|c|c|c|c|c|c|c|c|c|c|c|}
\hline & \multirow[b]{2}{*}{$\begin{array}{l}\text { Grain Size } \\
\quad(\mathrm{mm})\end{array}$} & \multirow[b]{2}{*}{ Density } & \multicolumn{3}{|c|}{$\begin{array}{l}\text { Frantz Isodynamic } \\
\text { Parameters }\end{array}$} & \multicolumn{2}{|c|}{$\begin{array}{c}\text { Concentration } \\
\text { (ppm) }, \pm 2 \%\end{array}$} & \multicolumn{3}{|c|}{$\begin{array}{l}\text { Isotopic Ratio } \\
2 \sigma \text { Error }\end{array}$} \\
\hline & & & $\begin{array}{l}\text { Counter } \\
\text { Slope }\end{array}$ & $\begin{array}{l}\text { Intensity } \\
\text { (A) }\end{array}$ & Attraction & $\mathrm{Sr}$ & $\mathrm{Rb}$ & ${ }^{87} \mathrm{Sr} /{ }^{86} \mathrm{Sr}$ & ${ }^{87} \mathrm{Rb}$ & ${ }^{86} \mathrm{Sr}$ \\
\hline \multicolumn{11}{|c|}{ Phengite } \\
\hline $4+a$ & $250-400$ & $2.9<-<3.3$ & - & - & - & 1076 & 37.4 & $0.703993 \pm 9$ & 0.1006 & 0.0029 \\
\hline $4+$ are & $250-400$ & $2.9<-<3.3$ & - & - & - & 1087 & 38.0 & $0.703994 \pm 9$ & 0.1011 & 0.0028 \\
\hline $4+b$ & $250-400$ & $2.9<-<3.3$ & $15^{\circ}$ & 1.25 & unattracted & 1137 & 33.1 & $0.703827 \pm 11$ & 0.0843 & 0.0026 \\
\hline $4+$ bre & $250-400$ & $2.9<-<3.3$ & $15^{\circ}$ & 1.25 & unattracted & 1160 & 33.6 & $0.703845 \pm 9$ & 0.0838 & 0.0023 \\
\hline $4+c$ & $250-400$ & $2.9<-<3.3$ & $15^{\circ}$ & 1.15 & attracted & 1192 & 35.7 & $0.703848 \pm 9$ & 0.0866 & 0.0027 \\
\hline $4+d$ & $250-400$ & $2.9<-<3.3$ & $15^{\circ}$ & 1.15 & unattracted & 1017 & 35.2 & $0.704002 \pm 9$ & 0.1001 & 0.0028 \\
\hline $2+a$ & $125-250$ & $2.9<-<3.3$ & $15^{\circ}$ & 1.5 & attracted & 1096 & 33.8 & $0.703881 \pm 9$ & 0.0892 & 0.0024 \\
\hline $2+$ are & $125-250$ & $2.9<-<3.3$ & $15^{\circ}$ & 1.5 & attracted & 1027 & 31.7 & $0.703867 \pm 6$ & 0.0893 & 0.0025 \\
\hline $2+b$ & $125-250$ & $2.9<-<3.3$ & $15^{\circ}$ & 1.5 & unattracted & 1248 & 24.7 & $0.703544 \pm 7$ & 0.0572 & 0.0014 \\
\hline $2+$ bre & $125-250$ & $2.9<-<3.3$ & $15^{\circ}$ & 1.5 & unattracted & 1257 & 23.8 & $0.703556 \pm 4$ & 0.0548 & 0.0016 \\
\hline $2+c$ & $125-250$ & $2.9<-<3.3$ & - & - & - & 1155 & 31.7 & $0.703821 \pm 7$ & 0.0792 & 0.0021 \\
\hline $1-$ & $100-125$ & $<2.9$ & - & - & - & 1208 & 29.7 & $0.703997 \pm 9$ & 0.1013 & 0.0018 \\
\hline \multicolumn{11}{|c|}{ Garnet } \\
\hline NOK 10d B & $250-400$ & $>3.3$ & $10^{\circ}$ & 0.3 & attracted & 15.65 & 0.260 & $0.703484 \pm 7$ & 0.0447 & 0.0022 \\
\hline NOK $10 \mathrm{~d} C$ & $250-400$ & $>3.3$ & $10^{\circ}$ & 0.32 & attracted & 8.64 & 0.207 & $0.703387 \pm 7$ & 0.0645 & 0.0013 \\
\hline NOK $10 \mathrm{~d} D$ & $250-400$ & $>3.3$ & $10^{\circ}$ & 0.32 & unattracted & 6.24 & 0.091 & $0.703502 \pm 9$ & 0.0394 & 0.0008 \\
\hline \multicolumn{11}{|c|}{ Symplectite } \\
\hline \multicolumn{11}{|c|}{ Whole Rock } \\
\hline Unleached & & & & & & 940 & 3.89 & $0.703293 \pm 6$ & 0.01198 & 0.00077 \\
\hline Leached $\mathrm{HCl}$ & & & & & & 979 & 2.92 & $0.703253 \pm 7$ & 0.00862 & 0.00049 \\
\hline Leached $\mathrm{HCl}$ & & & & & & 929 & 2.47 & $0.703246 \pm 7$ & 0.00768 & 0.00037 \\
\hline $2.5 \mathrm{~N}+6 \mathrm{~N}$ & & & & & & & & & & \\
\hline
\end{tabular}

fractions and one symplectite fraction (omphacite destabilized in amphiboles and plagioclases) were analyzed. Moreover, unleached whole-rock (WR), gently leached WR $(\mathrm{HCl} 2.5 \mathrm{~N})$, and strongly leached $\mathrm{WR}(\mathrm{HCl} 2.5 \mathrm{~N}$ and $6 \mathrm{~N})$ were investigated in both samples.

[16] The in situ trace element analyses [Schneider et al., 2007] are consistent with the concentrations measured during the multigrain fraction analyses, indicating that they reflect pure minerals. There is one exception: for the garnet fractions, the $\mathrm{Rb}$ and $\mathrm{Sr}$ content are dominated by the contribution of the alteration phases, mostly sodi-calcic amphibole, located in the fractures and developed during the late Caledonian amphibolite-facies metamorphism. The Sr-rich, Rb-poor minerals (i.e., Ep, Ky, Sy), and WR have ${ }^{87} \mathrm{Rb} /{ }^{86} \mathrm{Sr}$ ratios lower than 0.003 in sample NOK10a and lower than 0.011 in sample NOK10d (Tables 2 and 3 and Figures 3 and 4). The $\mathrm{Sr}$ - and $\mathrm{Rb}$-rich phengite is characterized by ${ }^{87} \mathrm{Rb} /{ }^{86} \mathrm{Sr}$ ratios ranging from 0.038 to 0.067 in sample NOK10a and from 0.055 to 0.1 in sample
NOK10d. For both samples, the Sr- and Rb-poor garnets yield intermediate ratios. Still, the ${ }^{87} \mathrm{Rb} /{ }^{86} \mathrm{Sr}$ ratios calculated for the phengite remain very low compared to the values of $\sim 70$ reported for this mineral in the literature [e.g., Paquette et al., 1989]. This difference is related to the nature of the protolith. Indeed, the amount of $\mathrm{Rb}$ and $\mathrm{Sr}$ that can potentially incorporate the crystalline lattice of phengite is constrained by the amount of these elements available in the protolith. The protolith of the studied samples are (plagioclase-rich) anorthosite and gabbro-anorthosite, characterized by high $\mathrm{Sr}(\sim 1000 \mathrm{ppm})$ and low $\mathrm{Rb}(<4 \mathrm{ppm})$. So despite a high partition coefficient, the $\mathrm{Rb}$ content of phengite is low $\left(15<\mathrm{Rb}_{\mathrm{ppm}}<38\right)$ compared to $\mathrm{Sr}\left(700<\mathrm{Sr}_{\mathrm{ppm}}<1250\right)$. Residues after WR acidleaching yield both ${ }^{87} \mathrm{Sr} /{ }^{86} \mathrm{Sr}$ and ${ }^{87} \mathrm{Rb} /{ }^{86} \mathrm{Sr}$ ratios lower than those of the unleached WR, suggesting the removal of a radiogenic ${ }^{87} \mathrm{Sr} /{ }^{86} \mathrm{Sr}$ component during the leaching step. This latter could correspond either to secondary alteration phases or to elements preferentially located in the interfoliar sites of the phengite. 
Table 4. Sm/Nd Results for Various Minerals From Samples NOK10a and NOK10d

\begin{tabular}{|c|c|c|c|c|}
\hline & \multicolumn{2}{|c|}{ Concentration (ppm), $\pm 2 \%$} & \multicolumn{2}{|c|}{ Isotopic Ratio $2 \sigma$ Error } \\
\hline & $\mathrm{Nd}$ & $\mathrm{Sm}$ & ${ }^{147} \mathrm{Sm} /{ }^{144} \mathrm{Nd}$ & ${ }^{143} \mathrm{Nd} /{ }^{144} \mathrm{Nd}$ \\
\hline \multicolumn{5}{|c|}{ NOK10a: Ky-rich eclogite } \\
\hline \multicolumn{5}{|c|}{ Garnet Leached } \\
\hline$A^{\prime}$ & 0.377 & 0.245 & $0.393 \pm 0.020$ & $0.513791 \pm 13$ \\
\hline $\mathrm{C}$ & 0.498 & 0.334 & $0.395 \pm 0.020$ & $0.513764 \pm 14$ \\
\hline D & 0.429 & 0.287 & $0.405 \pm 0.020$ & $0.513847 \pm 13$ \\
\hline $\mathrm{E}$ & 0.430 & 0.281 & $0.405 \pm 0.020$ & $0.513883 \pm 12$ \\
\hline \multicolumn{5}{|c|}{ Symplectite Foliation } \\
\hline & 0.847 & 0.133 & $0.095 \pm 0.005$ & $0.511985 \pm 7$ \\
\hline \multicolumn{5}{|c|}{ Symplectite Coronite } \\
\hline & 2.391 & 0.365 & $0.092 \pm 0.005$ & $0.511909 \pm 5$ \\
\hline \multicolumn{5}{|c|}{ Kyanite } \\
\hline & 0.425 & 0.085 & $0.121 \pm 0.006$ & $0.512098 \pm 8$ \\
\hline \multicolumn{5}{|c|}{ Whole Rock } \\
\hline & 0.701 & 0.138 & $0.119 \pm 0.006$ & $0.512270 \pm 7$ \\
\hline \multicolumn{5}{|c|}{ NOK10d: Ph-rich eclogite } \\
\hline \multicolumn{5}{|c|}{ Garnet Leached } \\
\hline B & 0.547 & 0.645 & $0.713 \pm 0.036$ & $0.515483 \pm 10$ \\
\hline $\mathrm{C}$ & 0.407 & 0.472 & $0.701 \pm 0.035$ & $0.515484 \pm 11$ \\
\hline \multirow[t]{5}{*}{$\mathrm{D}$} & 0.440 & 0.515 & $0.708 \pm 0.035$ & $0.515440 \pm 12$ \\
\hline & & ite Fol & & \\
\hline & 2.831 & 0.648 & $0.138 \pm 0.007$ & $0.512116 \pm 13$ \\
\hline & & le Roc & & \\
\hline & 3.813 & 0.974 & $0.154 \pm 0.008$ & $0.511940 \pm 7$ \\
\hline
\end{tabular}

[17] All the data, with exception of garnet data, define errorchrons in the ${ }^{87} \mathrm{Rb} /{ }^{86} \mathrm{Sr}$ versus ${ }^{87} \mathrm{Sr} /{ }^{86} \mathrm{Sr}$ diagram (Figures 3 and 4). Garnet fractions (not shown) spread more or less parallel to the vertical axis, probably reflecting the presence of alteration phases. Therefore, garnets were not considered in the discussion. Data from sample NOK10a (Figure 3) define an errorchron with an age of $471 \pm 19 \mathrm{Ma}$ and an ${ }^{87} \mathrm{Sr} /{ }^{86} \mathrm{Sr}$ initial value of $0.70297 \pm 1$. The scatter around the best fit line is high, as shown by the MSWD value (20). Using only eclogite-facies minerals (i.e., Grt and WR are excluded), the regression calculation yields a slightly younger age of $457 \pm 22 \mathrm{Ma}(\mathrm{MSWD}=$ 8.7), with a similar initial ratio of $0.70298 \pm 2$. The scatter of the analytical points suggests an isotopic disequilibrium between the various eclogite-facies minerals. A limited variation in the ${ }^{87} \mathrm{Rb} /{ }^{86} \mathrm{Sr}$ ratios for the entire data set is also responsible for the high MSWD value. Considering only the phengite fractions, a significantly older and less precise age of $525 \pm 90 \mathrm{Ma}$ is obtained, in spite of a lower MSWD value of 3.7. This suggests a strong isotopic disequilibrium between the different phengite populations. A careful examination of the repartition of the phengite data points in the isochron diagram reveals that the phengite fractions can be separated into two groups which define two distinct correlations (Figure 3b). A first group of six fractions yields an age of $457 \pm 71 \mathrm{Ma}(\mathrm{MSWD}=0.069)$ and an initial ratio of $0.70297 \pm 6$. A second group, also composed of six fractions, provides an age of $672 \pm 180 \mathrm{Ma}(\mathrm{MSWD}=0.024)$ with an intercept at $0.70282 \pm 2$. For both groups, the age error margins remain high despite probability coefficient values higher than $99 \%$. This feature is attributed to the narrow range of the ${ }^{87} \mathrm{Rb} /{ }^{86} \mathrm{Sr}$ ratios measured for the various fractions (Table 2). Two fractions $(1-b$ and $1+b)$ do not lie on these two distinct alignments and were excluded from the age calculation. For the sake of convenience later in the text, these two latter fractions will be called "group 1," fractions plotted on the $457 \pm 71 \mathrm{Ma}$ 
Table 5. Ar/Ar Data for Sample NOK10a

\begin{tabular}{|c|c|c|c|c|c|c|c|c|c|}
\hline & Step & ${ }^{40} \mathrm{Ar} *{ }^{39} \mathrm{Ar}$ & $\begin{array}{c}\mathrm{Ar} /{ }^{40} \mathrm{Ar} \times 1000 \\
\mathrm{~J}=0.01218\end{array}$ & ${ }^{39} \mathrm{Ar} /{ }^{40} \mathrm{Ar}$ & ${ }^{37} \mathrm{Ar} /{ }^{39} \mathrm{Ar}$ & $\%^{39} \mathrm{Ar}$ & $\%$ Atm & $\begin{array}{l}\text { Age } \\
\mathrm{Ma})\end{array}$ & $\begin{array}{l}\text { Error } \\
(1 \sigma)\end{array}$ \\
\hline \multicolumn{10}{|c|}{ NOK10a Phengite N10A4MA } \\
\hline 1 & & 24.998 & 0.157 & 0.038 & 0 & 1.0 & 4.6 & 479.6 & 33.9 \\
\hline 2 & & 23.024 & 0.022 & 0.043 & 0 & 41.0 & 0.6 & 446.0 & 2.0 \\
\hline 3 & & 22.642 & 0.007 & 0.044 & 0 & 71.3 & 0.2 & 439.4 & 1.5 \\
\hline 4 & & 22.237 & 0.021 & 0.045 & 0 & 79.8 & 0.6 & 432.4 & 2.7 \\
\hline 5 & & 22.116 & 0.032 & 0.045 & 0 & 83.6 & 0.9 & 430.3 & 6.1 \\
\hline 6 & & 22.576 & 0.058 & 0.044 & 0 & 95.7 & 1.7 & 438.3 & 2.3 \\
\hline 7 & & 23.527 & 0.026 & 0.042 & 0 & 100.0 & 0.7 & 454.6 & 5.5 \\
\hline
\end{tabular}

Total age $=442.0 \pm 4.0 \mathrm{Ma}$

Pseudoplateau age $(2-7)=442.1 \pm 4.1 \mathrm{Ma}$

NOK10a Phengite N10A4MA2

$\begin{array}{llllllll}38.838 & 1.300 & 0.016 & 0 & 0.0 & 38.4 & 698.8 & 769.4 \\ 36.335 & 0.898 & 0.020 & 0 & 0.1 & 26.5 & 661.1 & 161.9 \\ 29.374 & 0.877 & 0.025 & 0 & 0.9 & 25.9 & 551.8 & 30.7 \\ 23.306 & 0.110 & 0.041 & 0 & 30.9 & 3.2 & 450.8 & 1.9 \\ 23.265 & 0.018 & 0.043 & 0 & 85.5 & 0.5 & 450.1 & 1.4 \\ 22.054 & 0.149 & 0.043 & 0 & 89.6 & 4.4 & 429.3 & 8.0 \\ 23.692 & 0.011 & 0.042 & 0 & 100.0 & 0.3 & 457.4 & 3.2\end{array}$

Total age $=451.4 \pm 4.1 \mathrm{Ma}$

Pseudoplateau age $(4-7)=450.3 \pm 4.1 \mathrm{Ma}$

NOK10a Phengite N10A4MA3

$\begin{array}{llllllll}10.459 & 1.081 & 0.065 & 0 & 0.0 & 31.9 & 216.3 & 384.4 \\ 21.107 & 0.516 & 0.040 & 0 & 0.3 & 15.2 & 412.8 & 36.8 \\ 22.826 & 0.252 & 0.041 & 0 & 1.5 & 7.4 & 442.6 & 10.0 \\ 21.523 & 0.300 & 0.042 & 0 & 2.2 & 8.8 & 420.1 & 19.9 \\ 22.788 & 0.046 & 0.043 & 0 & 4.5 & 1.3 & 442.0 & 6.6 \\ 22.989 & 0.002 & 0.043 & 0 & 16.6 & 0.0 & 445.4 & 2.1 \\ 22.827 & 0.016 & 0.044 & 0 & 41.9 & 0.4 & 442.6 & 1.9 \\ 22.577 & 0.023 & 0.044 & 0 & 61.6 & 0.6 & 438.3 & 1.6 \\ 22.241 & 0.033 & 0.045 & 0 & 69.7 & 0.9 & 432.5 & 3.2 \\ 22.250 & 0.062 & 0.044 & 0 & 82.3 & 1.8 & 432.7 & 1.8 \\ 21.980 & 0.064 & 0.045 & 0 & 84.0 & 1.9 & 428.0 & 6.3 \\ 22.732 & 0.002 & 0.044 & 0 & 100.0 & 0.0 & 441.0 & 1.7\end{array}$

Total age $=439.1 \pm 3.9 \mathrm{Ma}$

Pseudoplateau age $(5-12)=439.4 \pm 4.0 \mathrm{Ma}$

NOK10a Phengite N10A4MB1

1
2
3
4
5
6

Total age $=439.9 \pm 4.3 \mathrm{Ma}$

Pseudoplateau age $(1-6)=439.9 \pm 4.3 \mathrm{Ma}$

$\begin{array}{llllllll}22.791 & 0.108 & 0.042 & 0 & 58.0 & 3.2 & 442.0 & 1.9 \\ 22.137 & 0.181 & 0.043 & 0 & 72.6 & 5.3 & 430.7 & 5.8 \\ 22.979 & 0.035 & 0.043 & 0 & 82.6 & 1.0 & 445.2 & 6.6 \\ 21.779 & 0.171 & 0.044 & 0 & 87.6 & 5.0 & 424.5 & 13.3 \\ 21.584 & 0.256 & 0.043 & 0 & 90.1 & 7.5 & 421.1 & 38.5 \\ 23.175 & 0.057 & 0.042 & 0 & 100.0 & 1.6 & 448.6 & 4.2\end{array}$

1
2
3
4
5
6
7
8
Total age $=459.9 \pm 4.3 \mathrm{Ma}$
Pseudoplateau age $(4-8)=458.8 \pm 4.2 \mathrm{Ma}$

NOK10a Phengite N10A4MB2

$\begin{array}{llllllll}17.797 & 1.746 & 0.027 & 0 & 0.1 & 51.6 & 354.0 & 221.1 \\ 24.921 & 0.575 & 0.033 & 0 & 3.3 & 17.0 & 478.3 & 24.6 \\ 26.599 & 0.029 & 0.037 & 0 & 4.6 & 0.8 & 506.3 & 19.8 \\ 23.779 & 0.137 & 0.040 & 0 & 9.8 & 4.0 & 458.9 & 4.0 \\ 24.344 & 0.005 & 0.041 & 0 & 19.0 & 0.1 & 468.5 & 3.9 \\ 23.749 & 0.014 & 0.042 & 0 & 78.9 & 0.4 & 458.4 & 1.7 \\ 23.224 & 0.053 & 0.042 & 0 & 90.1 & 1.5 & 449.4 & 3.0 \\ 24.017 & 0.005 & 0.041 & 0 & 100.0 & 0.1 & 463.0 & 4.1\end{array}$

Pseudoplateau age $(4-8)=458.8 \pm 4.2 \mathrm{Ma}$ 
Table 5. (continued)

\begin{tabular}{|c|c|c|c|c|c|c|c|c|}
\hline & ${ }^{40} \mathrm{Ar} * /{ }^{39} \mathrm{Ar}$ & $\begin{array}{c}{ }^{36} \mathrm{Ar} /{ }^{40} \mathrm{Ar} \times 1000 \\
\mathrm{~J}=0.01218\end{array}$ & ${ }^{39} \mathrm{Ar} /{ }^{40} \mathrm{Ar}$ & ${ }^{37} \mathrm{Ar} /{ }^{39} \mathrm{Ar}$ & $\%{ }^{39} \mathrm{Ar}$ & $\%$ Atm & $\begin{array}{l}\text { Age } \\
\text { Ma) }\end{array}$ & $\begin{array}{c}\text { Error } \\
(1 \sigma)\end{array}$ \\
\hline \multicolumn{9}{|c|}{ NOK10a Phengite N10A4MC } \\
\hline 1 & -13.244 & 4.552 & 0.026 & 0 & 0.0 & 100.0 & 0.0 & 0.0 \\
\hline 2 & 38.289 & 0.183 & 0.025 & 0 & 0.5 & 5.4 & 690.6 & 153.0 \\
\hline 3 & 23.637 & 1.281 & 0.026 & 0 & 2.7 & 37.8 & 456.5 & 39.5 \\
\hline 4 & 27.164 & 0.165 & 0.035 & 0 & 3.5 & 4.8 & 515.7 & 102.5 \\
\hline 5 & 24.372 & 0.068 & 0.040 & 0 & 5.7 & 2.0 & 469.0 & 29.7 \\
\hline 6 & 24.628 & 0.366 & 0.036 & 0 & 7.3 & 10.8 & 473.3 & 40.4 \\
\hline 7 & 23.294 & 0.614 & 0.035 & 0 & 9.1 & 18.1 & 450.6 & 30.2 \\
\hline 8 & 23.855 & 0.085 & 0.041 & 0 & 54.5 & 2.5 & 460.2 & 2.3 \\
\hline 9 & 22.127 & 0.189 & 0.043 & 0 & 81.5 & 5.6 & 430.5 & 4.2 \\
\hline 10 & 23.270 & 0.107 & 0.042 & 0 & 92.9 & 3.1 & 450.2 & 8.3 \\
\hline 11 & 24.131 & 0.021 & 0.041 & 0 & 100.0 & 0.6 & 464.9 & 7.1 \\
\hline \multirow{2}{*}{\multicolumn{9}{|c|}{$\begin{array}{l}\text { Total age }=452.9 \pm 5.0 \mathrm{Ma} \\
\text { Pseudoplateau age }(7-11)=450.6 \pm 4.5 \mathrm{Ma}\end{array}$}} \\
\hline & & & & & & & & \\
\hline \multicolumn{9}{|c|}{ NOK10a Phengite N10CE1 } \\
\hline 1 & 24.434 & 0.106 & 0.040 & 0 & 3.1 & 470.0 & 6.4 & \\
\hline 2 & 23.790 & 0.039 & 0.041 & 0 & 1.1 & 459.1 & 2.7 & \\
\hline 3 & 20.444 & 0.493 & 0.042 & 0 & 14.5 & 401.2 & 15.7 & \\
\hline 4 & 23.128 & 0.018 & 0.043 & 0 & 0.5 & 447.8 & 1.6 & \\
\hline 5 & 23.346 & 0.004 & 0.043 & 0 & 0.1 & 451.5 & 2.2 & \\
\hline 6 & 22.918 & 0.015 & 0.043 & 0 & 0.4 & 444.2 & 2.1 & \\
\hline 7 & 22.033 & 0.021 & 0.045 & 0 & 0.6 & 428.9 & 8.2 & \\
\hline 8 & 23.761 & 0.107 & 0.041 & 0 & 3.1 & 458.6 & 1.3 & \\
\hline 9 & 21.781 & 0.148 & 0.044 & 0 & 4.3 & 424.5 & 2.6 & \\
\hline 10 & 22.979 & 0.007 & 0.043 & 0 & 0.2 & 445.2 & 2.7 & \\
\hline 11 & 22.659 & 0.045 & 0.044 & 0 & 1.3 & 439.7 & 8.9 & \\
\hline \multicolumn{9}{|c|}{ NOK10a Total Fusion One Grain N10A2P } \\
\hline & 23.855 & 0.036 & 0.041 & 0 & 1.1 & 460.2 & 2.3 & \\
\hline
\end{tabular}

isochron will be called "group 2," and fractions defining the age of $672 \pm 180$ Ma will be called "group 3."

[18] For the NOK10d sample, the entire data set (excluding Grt) yields an apparent age of $547 \pm$ $38 \mathrm{Ma}(\mathrm{MSWD}=33)$ and an initial ratio of $0.70318 \pm 2$ (Figure 4). The large scatter of the data supports a strong isotopic disequilibrium between the different phases. When only phengite fractions are used in the calculation, the age is $694 \pm 49 \mathrm{Ma},\left(\mathrm{MSWD}=2.7 ;{ }^{87} \mathrm{Sr} /{ }^{86} \mathrm{Sr}_{\mathrm{i}}=0.70304 \pm\right.$ 12). The phengite data remain scattered along the regression line, suggesting a disequilibrium within the different phengite populations.

\subsection{Ar/Ar Dating}

[19] In sample NOK10a, three single phengite grains from fraction 4-a provide ages of $442.1 \pm$ $4.1,450.3 \pm 4.1$, and $439.4 \pm 4.0 \mathrm{Ma}$, respectively, for a large percentage of the argon released (Figures 5a, 5b, and 5c and Table 5). In the present case, due to the presence of some heterogeneously distributed excess argon, these ages do not strictly fulfill the criteria for plateau age [Fleck et al., 1977]. However, the apparent ages used to calculate these partial ages do not show extreme variations. Two grains from fraction 4-b yield ages of $458.8 \pm 4.2$ and $439.9 \pm 4.4 \mathrm{Ma}$ (Figures $5 \mathrm{~d}$ and 5e and Table 5) and one grain from fraction 4-c has an age of $450.6 \pm$ $4.5 \mathrm{Ma}$ (Figure $5 \mathrm{f}$ and Table 5). No significant age variation can be observed between grains of different sizes, but none of the calculated ages overlap within the error margins. The total fusion age obtained for the grain from fraction $2+\mathrm{a}$ is the oldest, with a value of $460.2 \pm 2.3 \mathrm{Ma}$ (Figure $6 \mathrm{~g}$ and Table 5). Eleven in situ analyses were done on grain N10CE1. The ages are spread between $401 \pm 16$ and $470 \pm 6 \mathrm{Ma}$ and therefore, overlap all those obtained by step heating or total fusion. Considering only those with an error margin lower than $1 \%$, the ages obtained scatter over more than $30 \mathrm{Ma}$ (between $424.5 \pm 2.6$ and $459.1 \pm 2.7 \mathrm{Ma}$, Table 5), with the oldest age obtained in the core and the youngest at the edge of the crystal (Figure 5g). 
Table 6. Ar/Ar Data for Sample NOK10d

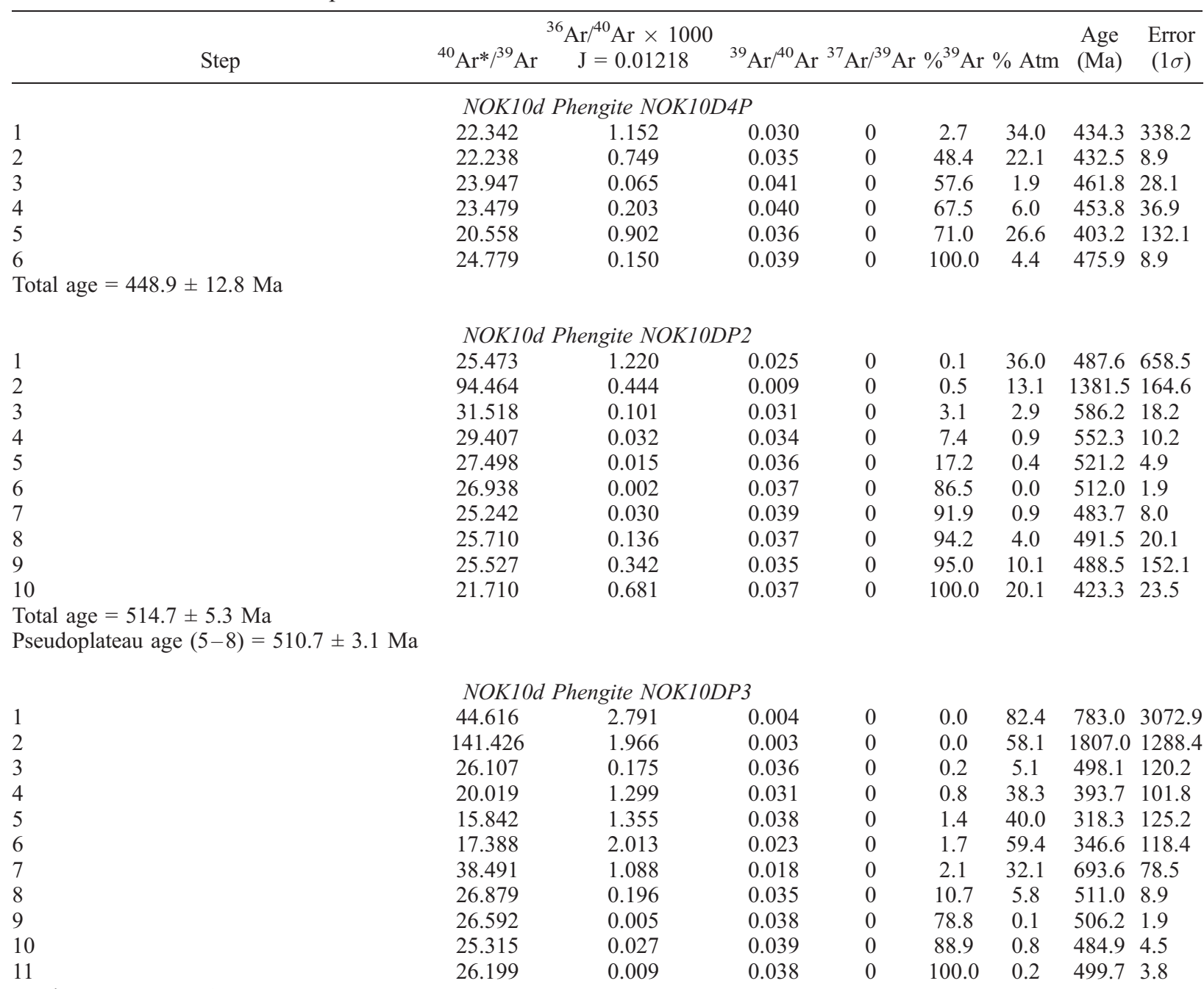

Total age $=502.7 \pm 4.8 \mathrm{Ma}$

Pseudoplateau age $(8-11)=503.7 \pm 4.7 \mathrm{Ma}$

NOK10d Total Fusion One Grain NOK10D2P

$$
\begin{array}{llcllll}
26.731 & 0.052 & 0.037 & 0 & 1.5 & 508.5 & 4.6
\end{array}
$$

NOK10d in Situ Polished Section S10D1 Phengite

$\begin{array}{llllllc}23.817 & 0.002 & 0.042 & 0 & 0.0 & 459.6 & 5.2 \\ 23.728 & 0.018 & 0.042 & 0 & 0.5 & 458.0 & 10.1 \\ 25.109 & 0.013 & 0.040 & 0 & 0.3 & 481.4 & 9.5 \\ 25.439 & 0.052 & 0.039 & 0 & 1.5 & 487.0 & 20.5 \\ 26.124 & 0.041 & 0.038 & 0 & 1.2 & 498.4 & 12.9 \\ 27.405 & 0.023 & 0.036 & 0 & 0.6 & 519.7 & 6.6 \\ 23.907 & 0.026 & 0.041 & 0 & 0.7 & 461.1 & 16.8 \\ 23.815 & 0.248 & 0.039 & 0 & 7.3 & 459.5 & 6.0\end{array}$

S10D2 Phengite

1

\begin{tabular}{|c|c|c|c|c|c|c|}
\hline \multicolumn{7}{|c|}{ S10D2 Phengite } \\
\hline 26.368 & 0.046 & 0.037 & 0 & 1.3 & 502.5 & 4.1 \\
\hline 25.295 & 0.051 & 0.039 & 0 & 1.5 & 484.6 & 1.4 \\
\hline 25.515 & 0.004 & 0.039 & 0 & 0.1 & 488.3 & 2.9 \\
\hline 25.396 & 0.089 & 0.038 & 0 & 2.6 & 486.3 & 4.1 \\
\hline \multicolumn{7}{|c|}{ Amphibole } \\
\hline 27.229 & 0.074 & 0.036 & 0.569 & 2.2 & 516.8 & 2.2 \\
\hline 27.095 & 0.051 & 0.036 & 1.125 & 1.5 & 514.6 & 2.4 \\
\hline 27.387 & 0.034 & 0.036 & 0.481 & 1.0 & 519.4 & 2.3 \\
\hline
\end{tabular}


Table 6. (continued)

\begin{tabular}{|c|c|c|c|c|c|c|c|c|c|}
\hline & \multicolumn{6}{|c|}{${ }^{36} \mathrm{Ar} /{ }^{40} \mathrm{Ar} \times 1000$} & $\%$ Atm & \multirow[t]{2}{*}{$\begin{array}{l}\text { Age } \\
\text { (Ma) }\end{array}$} & $\begin{array}{l}\text { Error } \\
(1 \sigma)\end{array}$ \\
\hline \multicolumn{9}{|c|}{ S10D3 Phengite } & \\
\hline 1 & & 24.936 & 0.006 & 0.040 & 0 & 0.2 & 478.5 & 5.0 & \\
\hline 2 & & 26.719 & 0.005 & 0.037 & 0 & 0.1 & 508.3 & 3.0 & \\
\hline 3 & & 27.350 & 0.003 & 0.037 & 0 & 0.0 & 518.8 & 1.8 & \\
\hline 4 & & 25.854 & 0.007 & 0.039 & 0 & 0.2 & 493.9 & 2.0 & \\
\hline 5 & & 26.380 & 0.001 & 0.038 & 0 & 0.0 & 502.7 & 1.6 & \\
\hline
\end{tabular}

[20] In sample NOK10d, the three grains analyzed by step heating provide ages of $510.7 \pm$ $3.1,503.7 \pm 4.7$, and $451.2 \pm 10.3 \mathrm{Ma}$, respectively (Figures 6a, 6b, and 6c and Table 6). The last age has a large analytical error due to the small size of the grain and to the low amount of argon released (Figure 6c). Total fusion of a phengite grain from fraction $2+\mathrm{a}$ yields an age of $508.5 \pm 4.6 \mathrm{Ma}$ (Table 6). In situ laser ablation analyses of phengite and amphibole (S10D1-3) were performed in a thick section of sample NOK10d, in crystals located in different textural positions. These include the core or rim of the phengite/epidote layer, pressure shadows around garnets, phengite in symplectites areas, etc. The data set does not show a correlation between textural location and apparent age. All together, the phengite data (19 ages) spread between $458.0 \pm 10.1$ and $519.7 \pm 6.6 \mathrm{Ma}$ (Figure $6 \mathrm{~d}$ and Table 6). The ages obtained from three amphibole grains are more consistent and range between $514.6 \pm 2.4$ and $519.4 \pm 2.3 \mathrm{Ma}$.

\subsection{Sm/Nd Dating}

[21] Four leached garnet fractions, two symplectite fractions (symplectite from the breakdown of diopside in coronites, and symplectite from the breakdown of omphacite from the main foliation), one kyanite, and the WR have been investigated for the NOK10a sample. In sample NOK10d, three leached garnet fractions, one symplectite fraction (breakdown of omphacite in the main foliation), and the WR were analyzed. Because omphacite has been widely destabilized in symplectite (primarily made of amphibole and plagioclase) during retrogression in the amphibolite facies, it was not possible to separate pure pyroxene to perform the
$\mathrm{Sm} / \mathrm{Nd}$ analyses and therefore, only the symplectite fractions were investigated.

[22] Garnet from the two samples is partly inherited from the granulite-facies assemblage (Table 1). In sample NOK10a only a very thin outer rim of the garnet has been reequilibrated during eclogitization whereas, in sample NOK10d an overgrowth of the secondary eclogite-facies garnet is clearly observed [Schneider et al., 2007]. Garnet fractions are therefore composed of a mixture between Grt 1 (granulitefacies garnet) and Grt 2 (eclogite-facies garnet). Yet, Grt 1 largely dominates in both samples, as Sm and $\mathrm{Nd}$ contents measured on garnet fractions match those measured in situ in Grt 1 by LA-ICP-MS. This also confirms that submicroscopic inclusions do not influence the REE budget of the garnet fractions [Schneider et al., 2007].

[23] In the ${ }^{147} \mathrm{Sm} /{ }^{144} \mathrm{Nd}$ versus ${ }^{143} \mathrm{Nd} /{ }^{144} \mathrm{Nd}$ diagram (Figure 7a), four garnet fractions from sample NOK10a plot very close from each other. No significant regression line can be extracted from these points. An errorchron with an age of $917 \pm$ $69 \mathrm{Ma}\left(\mathrm{MSWD}=13,{ }^{143} \mathrm{Nd} /{ }^{144} \mathrm{Nd}_{\mathrm{i}}=0.51142 \pm 12\right.$; Figure $8 \mathrm{a}$ ) is obtained by regressing all data points, including garnet, kyanite, symplectite, and wholerock data. An improved line with an age of $936 \pm$ $44 \mathrm{Ma}($ MSWD $=1.9$; Figure 7a) is obtained by discarding the whole-rock analysis. In sample NOK $10 d,{ }^{147} \mathrm{Sm} /{ }^{144} \mathrm{Nd}$ ratios of the garnet fractions range from 0.701 to 0.713 , and ${ }^{143} \mathrm{Nd} /{ }^{144} \mathrm{Nd}$ from 0.515440 to 0.515484 (Table 4). As this scale of variation is very limited, an isochron age cannot be deduced using garnet fractions alone. The age calculated using all of the data is $934 \pm 110 \mathrm{Ma}$ $\left(\mathrm{MSWD}=24 ;{ }^{143} \mathrm{Nd} /{ }^{144} \mathrm{Nd}_{\mathrm{i}}=0.51113 \pm 34\right)$

Figure 3. $\mathrm{Rb} / \mathrm{Sr}$ isochron diagrams for NOK10a eclogite. (a) All analytical points, (b) phengite fractions only. Age calculations, error margins, ${ }^{87} \mathrm{Sr} /{ }^{86} \mathrm{Sr}$ initial ratios, mean squared weighted deviates (MSWD) have been calculated using the Isoplot program of Ludwig [2001]. See Table 2 for analytical data. 

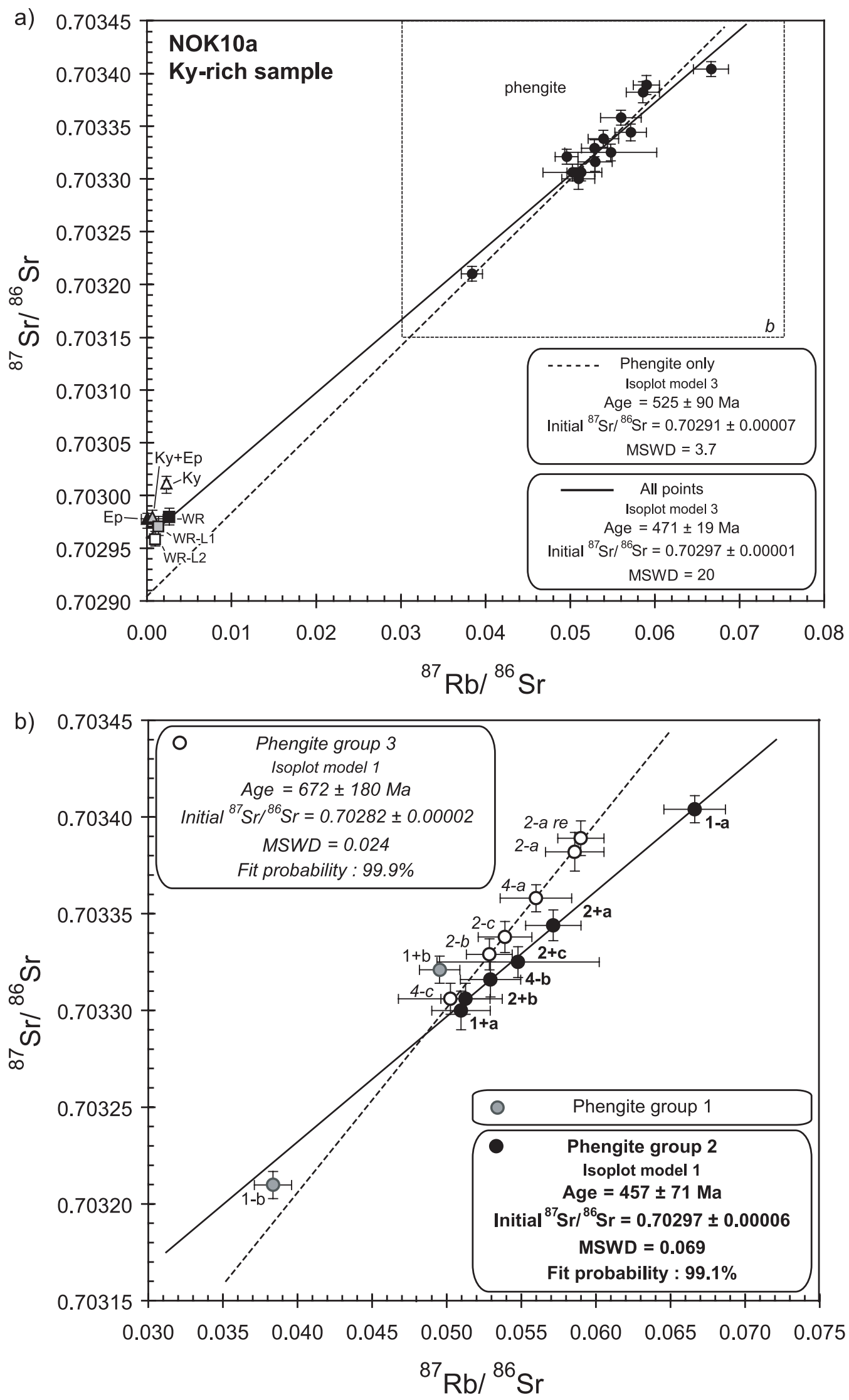

Figure 3 


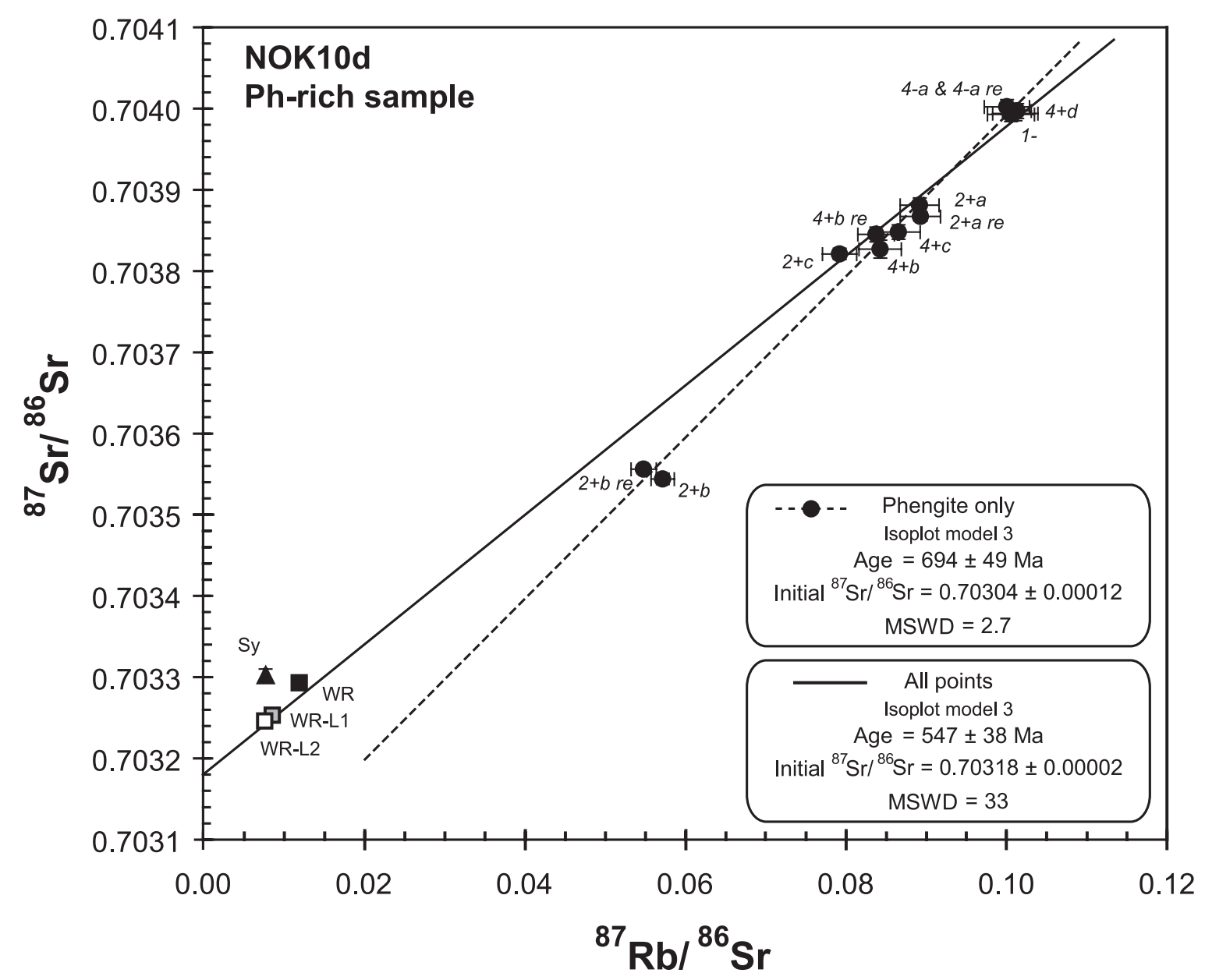

Figure 4. $\mathrm{Rb} / \mathrm{Sr}$ isochron diagram for NOK10d eclogite. See Table 3 for analytical data.

(Figure 7b). The large error and the high MSWD value are attributed to the scatter of data as a result of an isotopic disequilibrium between the different phases.

\section{Discussion}

[24] All $\mathrm{Rb} / \mathrm{Sr}$ and ${ }^{40} \mathrm{Ar} /{ }^{39} \mathrm{Ar}$ all apparent ages obtained in the two eclogite samples are intermediate between the reference age of the eclogitefacies event in the Lindås Nappe $(\sim 425 \mathrm{Ma})$ and the granulite-facies event ( $\sim 930 \mathrm{Ma})$. These ages have no geological significance as no metamorphic event is know in the study area in this time interval. Calculated $\mathrm{Sm} / \mathrm{Nd}$ ages are close to those commonly accepted for the granulite event. The differ- ent parameters that may have influenced the behavior of these three isotopic systems during the eclogite-facies metamorphic event are discussed below.

\section{1. $\mathrm{Rb} / \mathrm{Sr}$ System}

\subsubsection{Links Between Petrology and Geochronology}

[25] Schneider et al. [2007] correlated the phengite fractions studied here with the different petrographic/textural groups of phengite shown in section 3 characterized by distinct geochemical (major and trace elements) analyses. The results of this previous study are used here to correlate isotope data (phengite groups 1, 2, 3 as defined in Figure 3b)

Figure 5. (a-f) Age spectra of six single phengite grains from sample NOK10a. The height of the rectangle encompasses the error on the apparent age. (g) Age map of the phengite grain N10CE1 from sample NOK10a. The gray patches show the impact of the laser. See Table 5 for analytical data. 
Geochemistry

a)
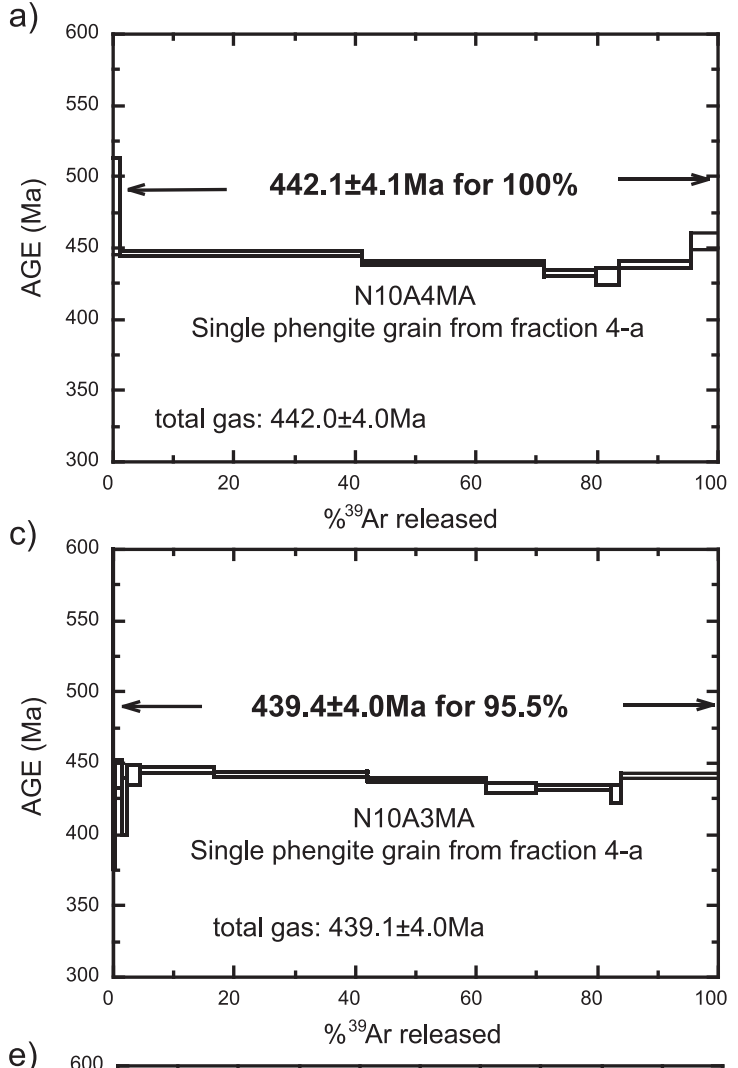

e)

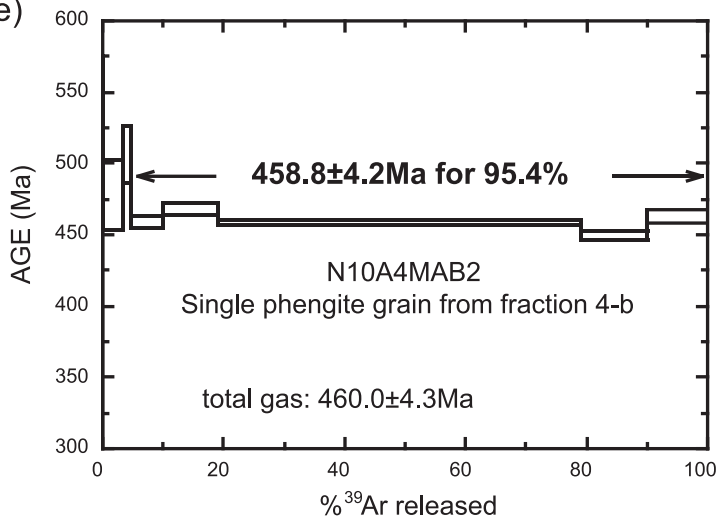

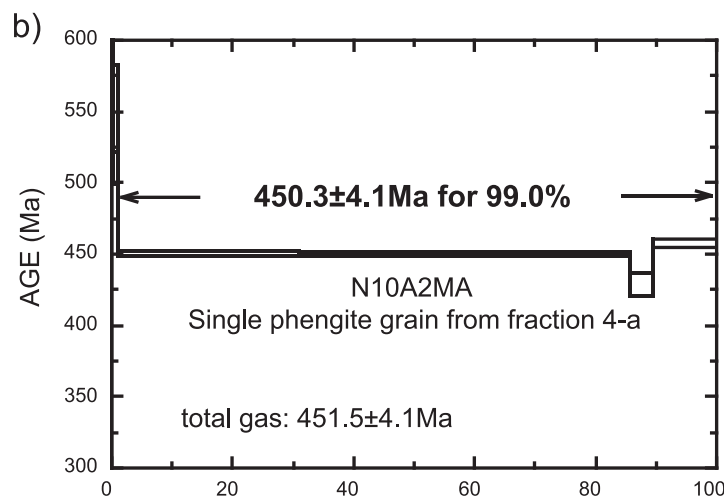
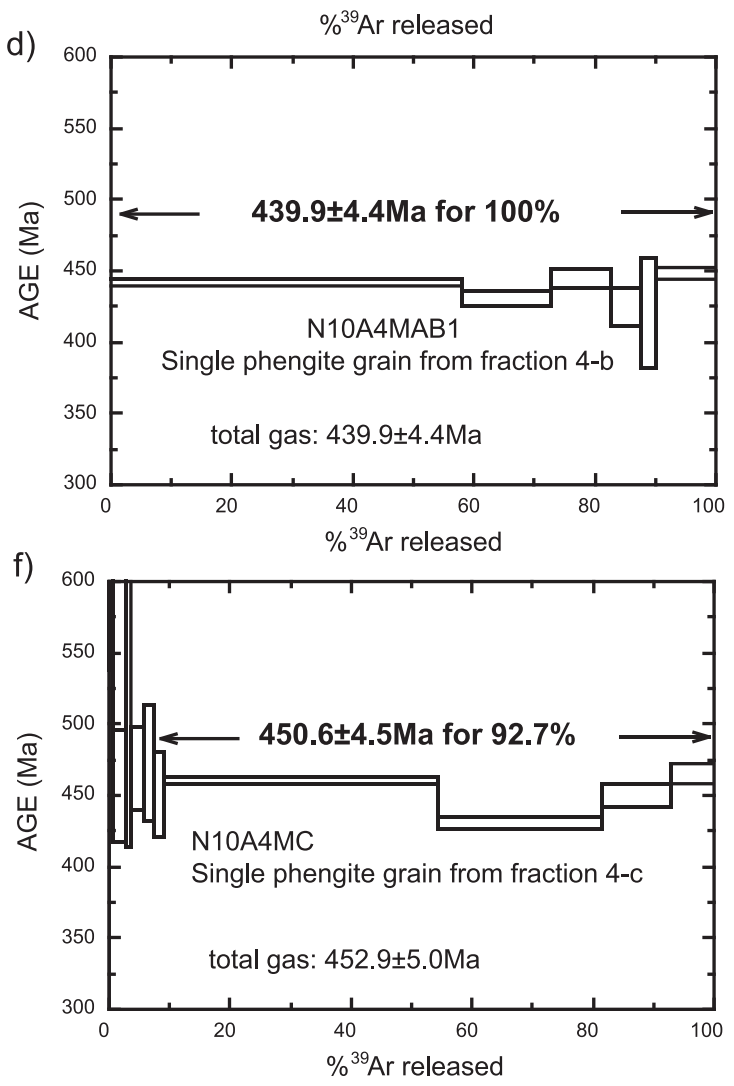

g)

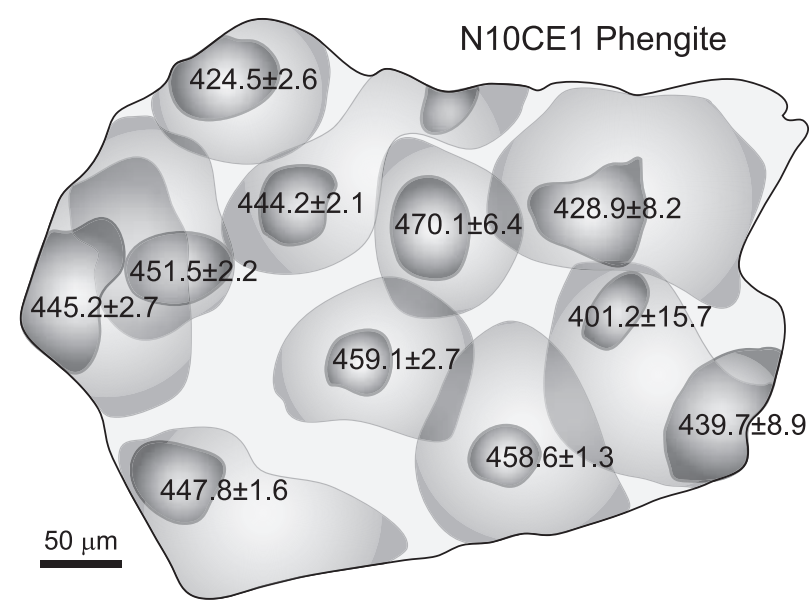

${ }^{40} \mathrm{Ar} /{ }^{39} \mathrm{Ar}$ dating of phengite grains from sample NOK10a

Figure 5 
a)

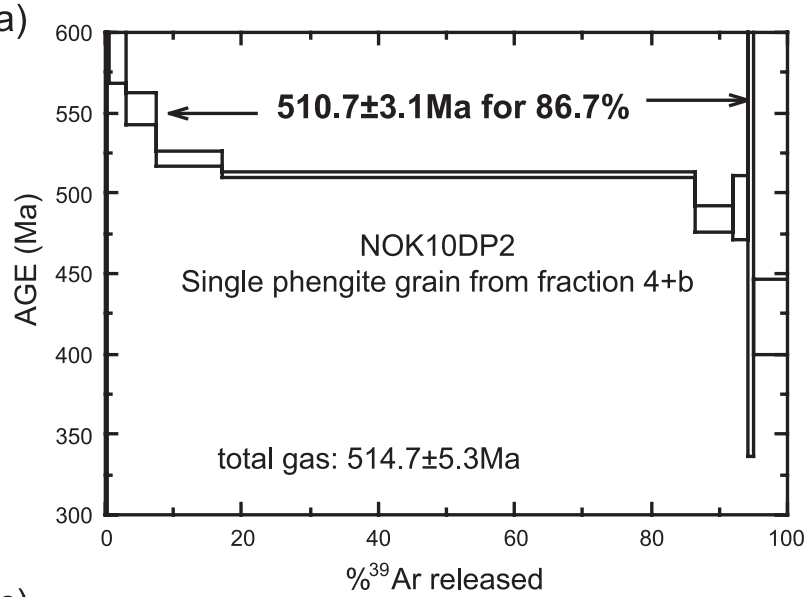

c)

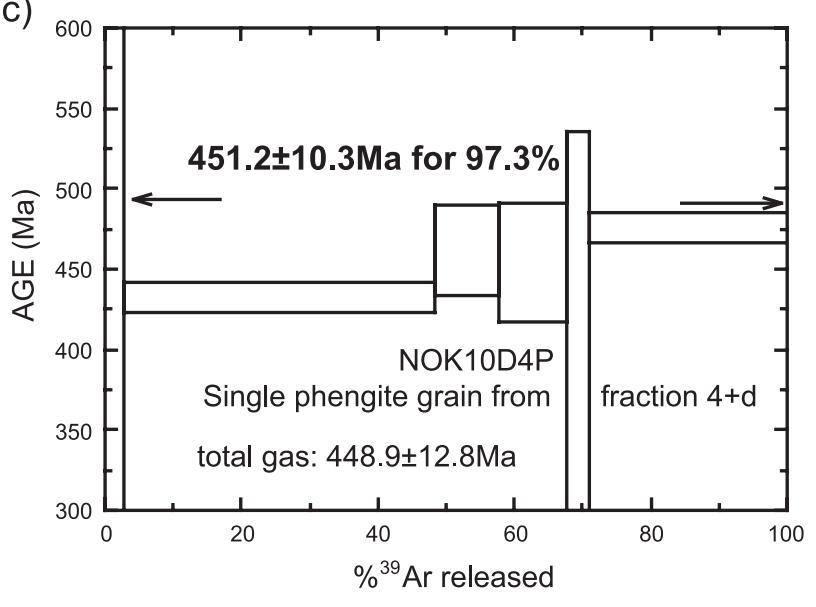

b)

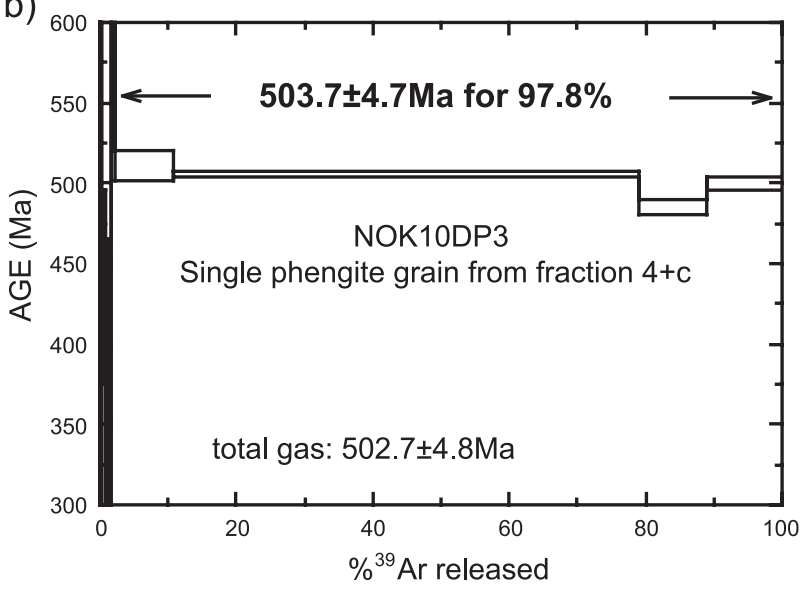

d)

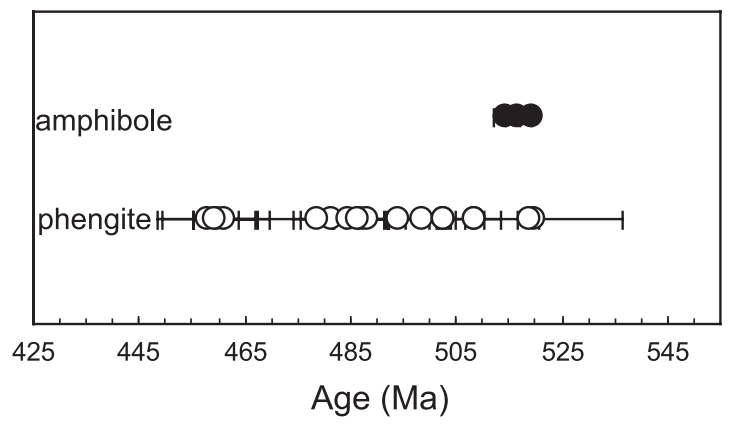

${ }^{40} \mathrm{Ar} /{ }^{39} \mathrm{Ar}$ dating of phengite and amphibole grains from sample NOK10d

Figure 6. $(a-c)$ Age spectra of six phengite grains from sample NOK10d. The error on the apparent age on each step is given by the height of the rectangle. (d) Argon ages obtained for in situ thick-section analyses of phengite and amphibole (S10D1-3). See Table 6 for analytical data.

with petrographic and geochemical data. Phengite from group 1, the two phengite fractions excluded from the age calculation of sample NOK10a, are the richest in HREE (Figure 8) and are interpreted as having been crystallized from garnet breakdown [Schneider et al., 2007]. The REE analyses of some of the phengite fractions from sample NOK10a show a well-marked positive Ce anomaly, which was interpreted as symptomatic of phengite grains that crystallized in quartz lenses after the precipitation of elements in excess carried by fluid [Schneider et al., 2007]. Boundy et al. [2002] demonstrated that the aqueous eclogitizing fluid was very oxidizing and therefore allowed the oxidation of $\mathrm{Ce}^{3+}$ into $\mathrm{Ce}^{4+}$. The $\mathrm{Ce}_{\mathrm{n}} / \mathrm{Ce}^{*}$ ratio for the different phengite fractions from the 1-2-3 phengite groups are reported in Figure 9. Phengite from group 2 and associated acid leachates have a significantly higher $\mathrm{Ce}_{\mathrm{n}} / \mathrm{Ce}^{*}$ ratio $(0.81-2.9)$ than those in groups $1(0.7-0.8)$ and $3(0.2-0.9$; auxiliary material). This feature, added to the fact that a young apparent age is obtained for the phengite fractions from group 2, suggests that these phengites predominantly come from the quartz lenses. The phengites from group 3 which yielded the apparent $\mathrm{Rb} / \mathrm{Sr}$ ages of $672 \pm 180 \mathrm{Ma}$ are interpreted as phengites from textural sites in equilibrium with epidotes (reaction (1)). The apparent age of group 3 from the NOK10a sample is close to the apparent age obtained for all of the phengite fractions from sample NOK10d (694 $\pm 49 \mathrm{Ma})$. Phengite fractions from the NOK10d sample, which present a homogeneous trace element content, only contain one phengite population, interpreted as having crystallized with epidote after the plagioclase breakdown during the eclogite facies. All of these observations 
a)

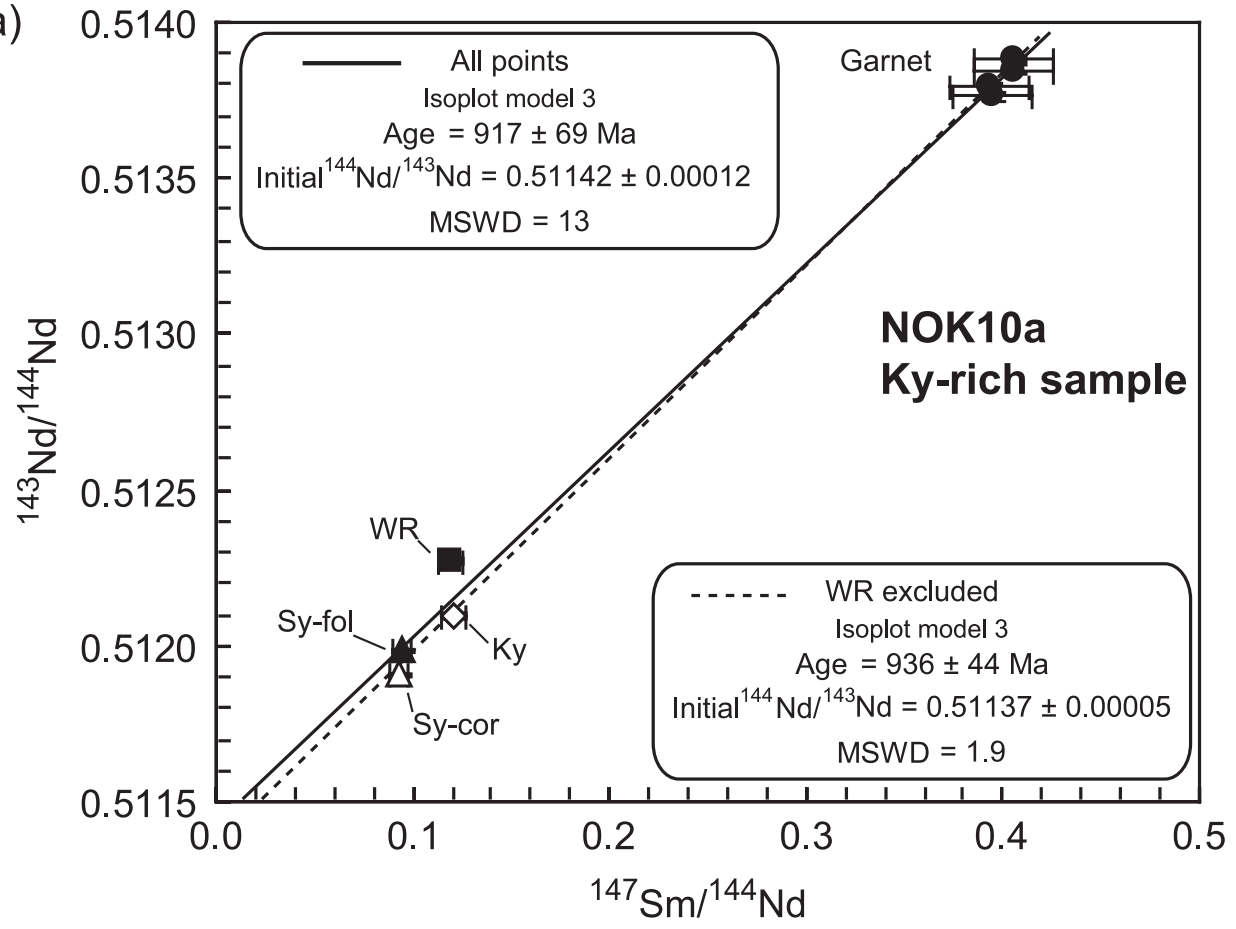

b)

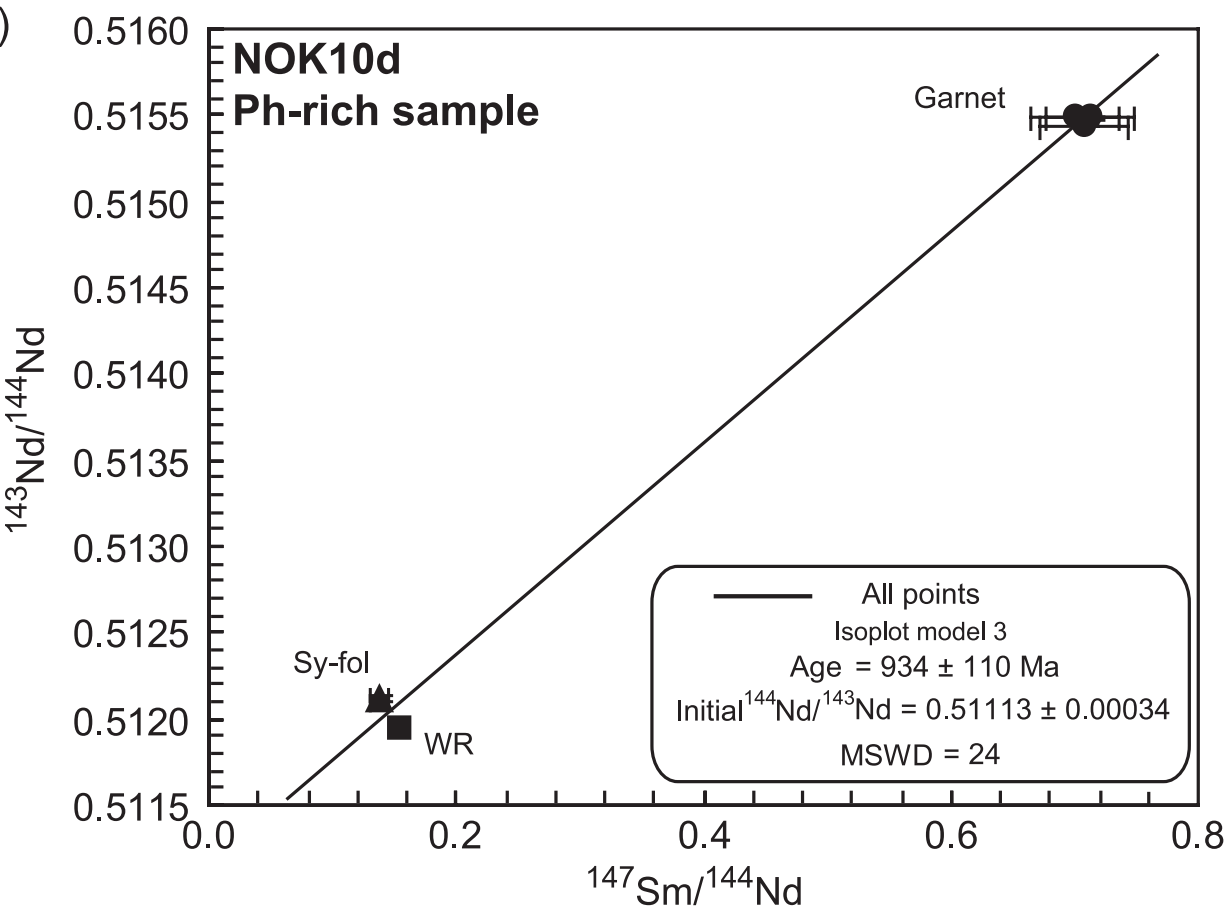

Figure 7. $\mathrm{Sm} / \mathrm{Nd}$ isochron diagram of eclogites (a) NOK10a and (b) NOK10d. See Table 4 for analytical data.

suggest a relationship between the textural sites where phengite crystallizes and its chemical and isotopic signatures. The main interpretations can be summarized as follows: (1) phengite populations crystallized after a plagioclase breakdown (group 3 from sample NOK10a and all of the fractions from sample NOK10d) yield similar ages of $\sim 672$ $694 \mathrm{Ma}$; (2) phengites formed by the precipitation of elements transported by the eclogitic fluid provide the youngest age approaching $425 \mathrm{Ma}$. 


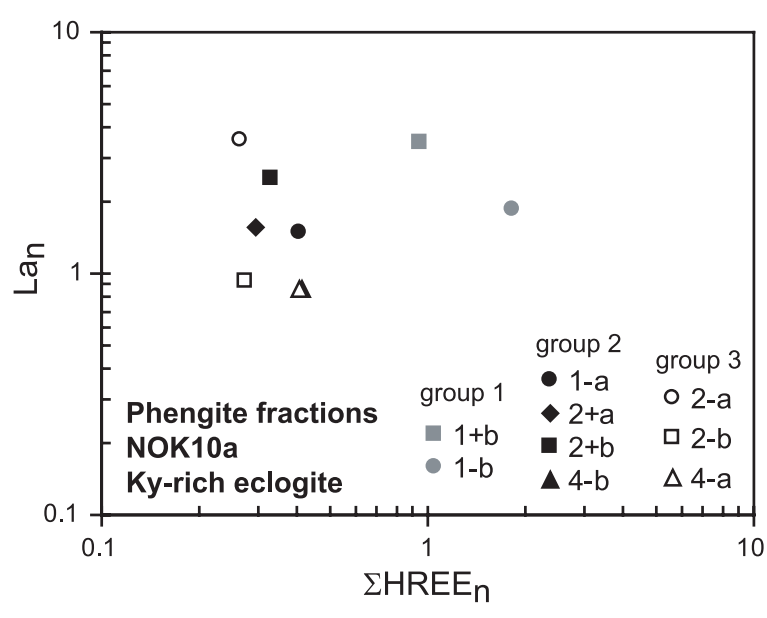

Figure 8. $\mathrm{La}_{\mathrm{n}}$ versus $\Sigma \mathrm{HREE}_{\mathrm{n}}$ (Dy to $\mathrm{Lu}$ ) of phengite fractions from sample NOK10a. Data from Schneider et al. [2007]. Normalization after Sun and McDonough [1989].

\subsubsection{Why Have $\mathrm{Rb} / \mathrm{Sr}$ Ages That Are "Too Old" Been Obtained in Phengites?}

[26] Several hypotheses can be proposed to explain why apparent $\mathrm{Rb} / \mathrm{Sr}$ errorchron ages are older than the eclogite-facies event. The first possibility is that they result from a mixture between minerals from different generations (i.e., from granulite and eclogite-facies metamorphic stages) [e.g., Santos Zalduegui et al., 1995]. In the present study, this assumption is unlikely since the granulite paragenesis was free from white micas, and a detailed petrological investigation on the phengite populations demonstrated that they crystallized during the Caledonian metamorphic event [Schneider et $a l .$, 2007]. This is further supported by X-ray diffractions which revealed that the phengite is made of pure minerals without inclusions and that no other phase developed in the interfoliar spaces (auxiliary material).

[27] Another hypothesis is that the system reached equilibrium during the eclogitic event but was disturbed and then partially reequilibrated later during a retrograde event. However, minerals altered during a retrograde amphibolite-facies event must yield ages that are intermediate between those of the peak metamorphism and the retrogression [e.g., Li et al., 2000]. Clearly, this is not the case here. Moreover, in sample NOK10d, the symplectite fraction is not in equilibrium with the phengite fractions (Figure 4). During the retrograde amphibolite-facies event, LILE (including Sr) have been relatively mobile at a sample scale [Schneider et al., 2007]. Therefore, if phengite behaved as an open system during the retrograde metamorphism, then chemical exchanges would have favored an isotopic equilibrium between phengite and symplectite.

[28] Another alternative is that the phengite ${ }^{87} \mathrm{Sr} /{ }^{86} \mathrm{Sr}$ isotopic ratio was modified during fluid circulation [e.g., Xie et al., 2004]. In order to be effective, this process requires that the external fluid has a very high $\mathrm{Sr}$ content and a ${ }^{87} \mathrm{Sr} /{ }^{86} \mathrm{Sr}$ ratio that is significantly distinct from that of the phengite. This process is unlikely due to (1) to the extremely high Sr content in the studied phengite (around 1000 ppm; Tables 2 and 3) combined with the low Sr content of the fluid [Rockow et al., 1997; Schneider et al., 2007]; (2) the fact that the ${ }^{87} \mathrm{Sr} /{ }^{86} \mathrm{Sr}$ ratio of the fluid was equilibrated with the wallrock [Glodny et al., 2008].

\subsubsection{Modeling of the $\mathrm{Rb} / \mathrm{Sr}$ System Behavior During the Recrystallization Processes}

[29] One important result from the present $\mathrm{Rb} / \mathrm{Sr}$ isotope data is the possible relationship between the crystallization mode (i.e., the mineralogical reaction from which the mineral crystallized) and the isotopic signature of the phengite population. On the basis of the chemical element distribution, Schneider et al. [2007] established that element migration during an eclogite-facies metamorphism

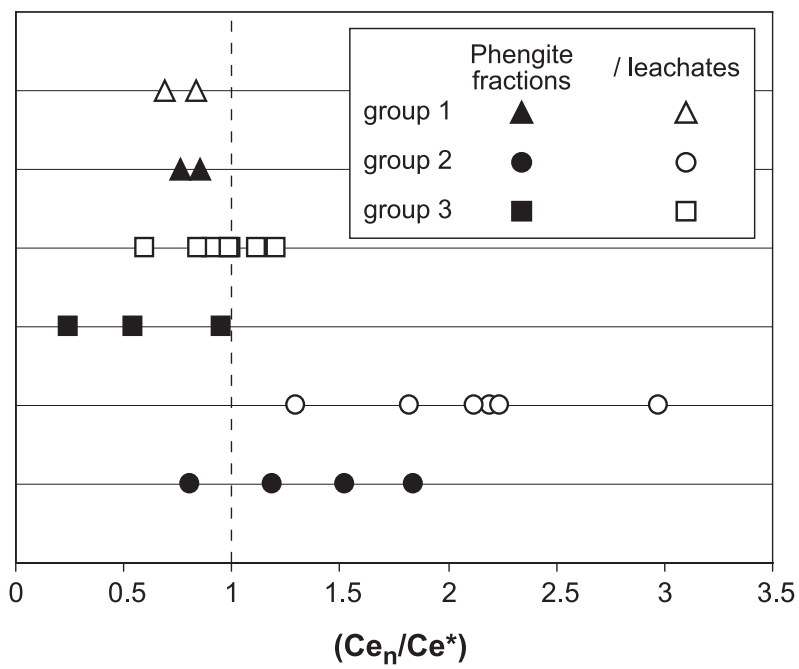

Figure 9. $\left(\mathrm{Ce}_{\mathrm{n}} / \mathrm{Ce}^{*}\right)$ ratio of phengite fractions and corresponding leachates for NOK10a sample. Phengite have been classified into three groups accordingly to $\mathrm{Rb} / \mathrm{Sr}$ behavior (Figure 3b). Ce* $=\left(\mathrm{La}_{\mathrm{n}}+\mathrm{Pr}_{\mathrm{n}}\right) / 2$. Data for phengite fractions are from Schneider et al. [2007]; see auxiliary material for leachates. Normalization after Sun and McDonough [1989]. 
was limited at a few hundred micron sized microdomains and that the neoformed minerals inherited their chemical features from precursor granulitefacies minerals. Based on these observations, a model for the $\mathrm{Rb} / \mathrm{Sr}$ system evolution during eclogite-facies metamorphism is proposed (Figure 10). The model will be discussed starting from few million years before the eclogite-facies metamorphism until now.

\subsubsection{Stage $0\left(t_{0}\right)$ Anteceding/Preceding Eclogitization: Eclogitization Minus dt}

[30] The initial granulite consists of garnet + diopside + plagioclase (Figure 10a). All of the mineralogical species are assumed to be in equilibrium at this stage. Thus, a few millions years before the eclogitic event, they are aligned on a $500 \mathrm{Ma}$ isochron, which represents the time spent between granulitization and eclogitization [Bingen et al., 2001, 2004; Kühn et al., 2002; Glodny et al., 2008]. According to the average $\mathrm{Rb}$ and $\mathrm{Sr}$ concentrations, either measured in our samples or reported in literature for the Lindås Nappe granulites-facies minerals $\left[0.002<\left(\mathrm{Rb}_{\mathrm{ppm}}\right)^{\mathrm{Grt}}<0.048\right.$; $0.007<\left(\mathrm{Sr}_{\mathrm{ppm}}\right)^{\mathrm{Grt}}<0.25 ; 0.01<\left(\mathrm{Rb}_{\mathrm{ppm}}\right)^{\mathrm{Di}}<0.1$; $75<\left(\mathrm{Sr}_{\mathrm{ppm}}\right)^{\mathrm{Di}}<85 ;\left(\mathrm{Sr}_{\mathrm{ppm}}\right)^{\mathrm{Pl}} \gg 1000 ;$ Cohen et al., 1988; Burton et al., 1995; Schneider et al., 2007], the different analytical points can be presented as seen in Figure 10a. Three analytical plagioclase points related to the microdomains having a slightly different chemical composition (mainly a function of the antiperthite proportion) are represented by a white circle. WR has been placed between these plagioclase points, since, as the latter are the Sr-richest minerals, they will have the main impact on the ${ }^{87} \mathrm{Sr} /{ }^{86} \mathrm{Sr}$ ratio.

\subsubsection{Stage $1\left(t_{1}\right)$ : Eclogitization}

[31] Granulite minerals break down into new stable eclogite-facies minerals according to reactions (1) (plagioclase breakdown) and (4) (garnet and diopside breakdown). Considering that these two mineralogical reactions operate independently [Schneider et al., 2007], we therefore assume that there is not an isotope redistribution between the new minerals crystallized during each reaction. In reaction (1), epidote strongly concentrates $\mathrm{Sr}$, compared to phengite $\left(\left(\mathrm{Sr}_{\mathrm{ppm}}\right)^{\mathrm{Ep}}>\right.$ 6000; $\left.\left(\mathrm{Sr}_{\mathrm{ppm}}\right)^{\mathrm{Ph}}<1400\right)$, and almost all of the $\mathrm{Rb}$ will be incorporated into the phengite $\left(\left(\mathrm{Rb}_{\mathrm{ppm}}\right)^{\mathrm{Ep}}<0.1 ;(\mathrm{Rb} \mathrm{ppm})^{\mathrm{Ph}}>15\right.$; Tables 2 and 3 ). Therefore, the $\mathrm{Rb} / \mathrm{Sr}$ ratio of the epidote will be close to zero, and the $\mathrm{Rb} / \mathrm{Sr}$ ratio of phengite will be significantly higher than in the precursor plagioclases (Figure 10a). The limited mobility of the chemical elements during eclogitization suggests that the phengite and epidote, which crystallized in the same individual microdomain, inherit their ${ }^{87} \mathrm{Sr} /{ }^{86} \mathrm{Sr}$ ratio from the plagioclase (Figure 10a). The external fluid involved in the crystallization of phengite and epidote is believed to have a negligible influence on the ${ }^{87} \mathrm{Sr} /{ }^{86} \mathrm{Sr}$ ratio of the neoformed minerals due to the very high $\mathrm{Sr}$ content of the granulite-facies plagioclase ( $\gg 1000 \mathrm{ppm})$. In reaction (4), it is likely that garnet 2 inherited its $\mathrm{Sr}$ isotopic composition from garnet 1 and omphacite from granulite-facies diopside. This process was previously described by Mørk and Mearns [1986] for the Sm/Nd system and by Zheng et al. [2002] for oxygen isotopes. Therefore, similar ${ }^{87} \mathrm{Sr} /{ }^{86} \mathrm{Sr}$ ratios have been assigned to precursor (Grt 1, Di) and neoformed (Grt 2, Omp) minerals at $t_{o}$ and $t_{1}$. Rutile is not represented since it is a minor reservoir of $\mathrm{Sr}$ and $\mathrm{Rb}$. As a consequence of these various features, the different mineral phases formed during the eclogite-facies metamorphism will be in a strong isotopic disequilibrium at the time of their crystallization $\left(t_{1}\right)$ (Figure 10a).

\subsubsection{Stage $2\left(t_{2}\right)$ : Eclogitization Plus dt}

[32] After crystallization $\left(t_{1}\right)$, the system remains open for isotopic exchanges during a limited period of time (dt). The system is closed at $t_{2}$. Between $t_{1}$ and $t_{2}$, the isotopic disequilibrium between the different mineral species can be corrected by isotopic exchanges involving diffusion processes. For a complete equilibrium of the system, the different phases should reach the whole rock ${ }^{87} \mathrm{Sr} /{ }^{86} \mathrm{Sr}$ ratio (Figure 10b). For several reasons that will be discussed later in the text, the process of isotopic re-equilibration by volume diffusion was limited between $t_{1}$ and $t_{2}$. This behavior has been schematically represented in Figure $10 \mathrm{~b}$ with mineral points at $t_{2}$ located midway between their position at $t_{1}$ and the isotopic equilibrium line (i.e., $0 \mathrm{Ma}$ line).

Figure 10. Conceptual evolution of the ${ }^{87} \mathrm{Rb} /{ }^{86} \mathrm{Sr}$ and ${ }^{87} \mathrm{Sr} /{ }^{86} \mathrm{Sr}$ ratios of the granulite-facies and eclogite-facies mineral species just before, during, and just after the eclogite-facies metamorphic event. Shown are (a) $\mathrm{t}_{0}=$ eclogitization $-\mathrm{dt}=$ just prior eclogitization reactions; $\mathrm{t}_{1}=$ eclogitization $=$ breakdown of the granulite-facies minerals and crystallization of the eclogite-facies minerals; (b) $t_{2}=$ eclogitization $+d t=$ time interval between mineral crystallization and closure of the system; $(c) t_{3}=$ present time $=\sim 425 \mathrm{Ma}$ after $t_{2}$. See text for details. 

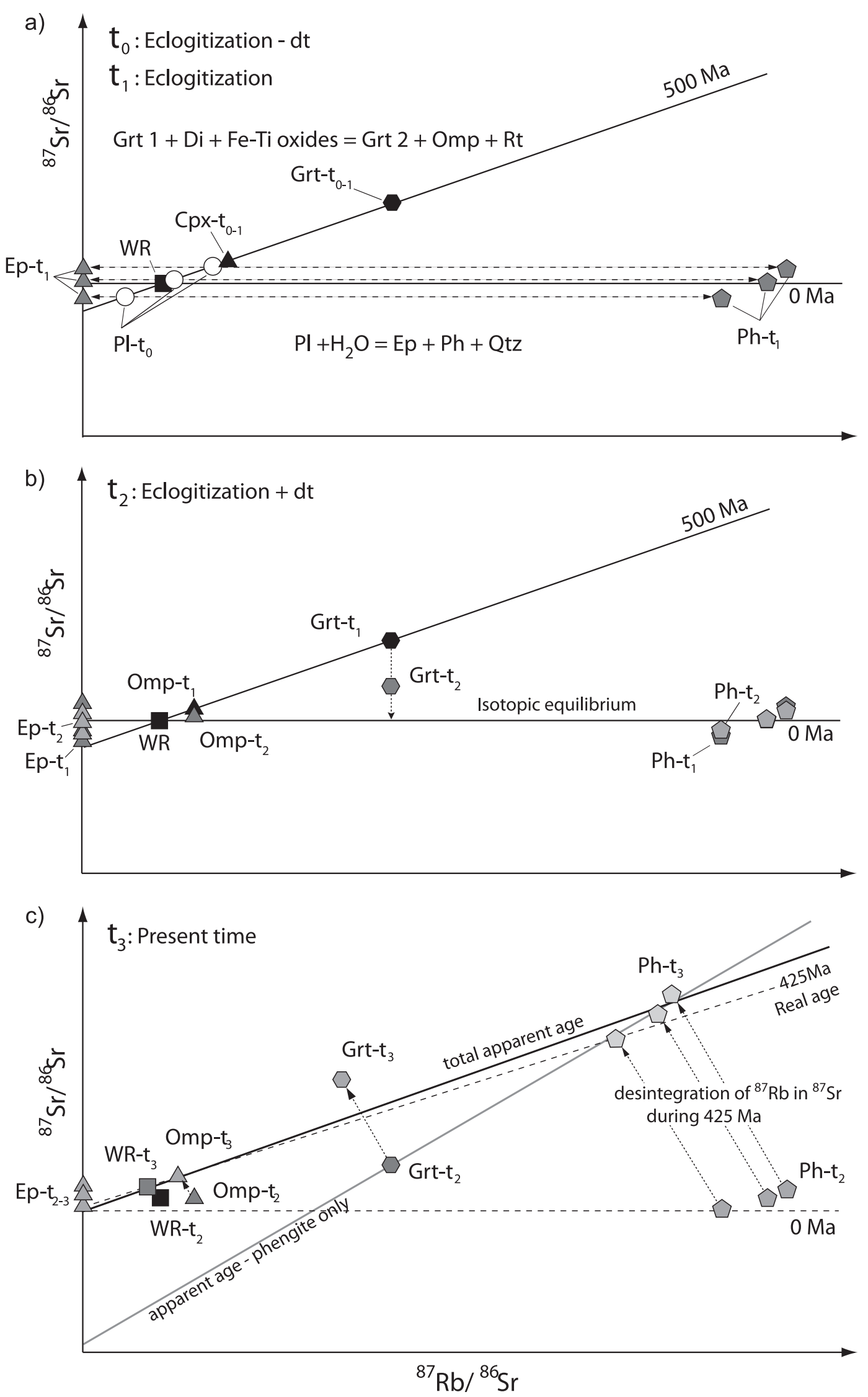

Figure 10 


\subsubsection{Stage $3\left(t_{3}\right)$ : Present Time}

[33] After the decay of ${ }^{87} \mathrm{Rb}$ during c. $425 \mathrm{Ma}$ (represented by dashed arrows in Figure 10c), the following specific features are obtained: (1) the phengite fractions are aligned along an isochron that gives an apparent age intermediate between the granulitization and eclogitization ages, (2) the age calculated for the phengite fractions alone is older than the age obtained with all of the mineral phases, (3) the ${ }^{87} \mathrm{Sr} /{ }^{86} \mathrm{Sr}$ initial ratio calculated for the phengite population alone is lower than the initial ratio obtained when all of the mineral phases were analyzed.

\subsubsection{Diffusion Efficiency During Retrogression}

[34] The late amphibolite-facies metamorphism took place $\sim 15 \mathrm{Ma}$ after the crystallization of the eclogite-facies minerals [Bingen et al., 2001; Glodny et al., 2008] at metamorphic conditions estimated between 650 and $690^{\circ} \mathrm{C}$ for a minimum pressure of 10-12 kbar [e.g., Boundy et al., 1996]. The peak temperature for the eclogite facies was estimated at around $700-750^{\circ} \mathrm{C}$ [Jamtveit et al., 1990; Raimbourg et al., 2007], which implies that the system has been maintained at over $650^{\circ} \mathrm{C}$ during at least $15 \mathrm{Ma}$. In such conditions, the various mineralogical phases, which were initially in a strong isotopic disequilibrium at the time of their crystallization, could potentially reach an equilibrium via diffusion processes during this time interval. A diffusion process implies element fluxes between a given mineral species (in this case, phengite) and a phase acting as an exchange partner [Dodson, 1973; Jenkin, 1997]. Fluid, which evolved in a closed system, can incorporate elements in excess (including Sr) released during the eclogite- and amphibolite-facies metamorphic reactions and thus, can potentially act as a good exchange partner during isotopic equilibrium processes. Epidote could also be a valuable exchange partner, given its high Sr content. But as epidote and phengite from the same microdomain probably have a similar ${ }^{87} \mathrm{Sr} /{ }^{86} \mathrm{Sr}$ initial ratio (inherited from precursor granulite-facies plagioclase), they need to exchange $\mathrm{Sr}$ either with phengite and epidote from another microdomain or with a fluid phase.

[35] It has been demonstrated that the intracrystalline diffusion in hydrous conditions is higher, by several orders of magnitude, than in an anhydrous environment [Giletti and Yund, 1984; Farquhar et al., 1996]. Moreover, Jenkin et al. [1995] used numerical modeling to show that inter-granular diffusion can be very effective in reaching an isotopic equilibrium. In this case, the exchanges primarily operate at the grain boundary, on the few nanometer-thick rims. Accordingly, depending on the total amount of $\mathrm{Sr}$ available in the epidote rim, this diffusion process can be more or less efficient in promoting a phengite isotopic equilibrium. Volume diffusion subsequently allows the homogenization of the concentration gradients between the phengite core and rim. Yet, this finite reservoir model [Jenkin et al., 1995; Jenkin, 1997] anticipates a strong control of the modal composition in the isotopic equilibrium process. In the present study, this process is expected to be more efficient in phengite-poor samples (e.g., sample NOK10a) than in phengite-rich samples (e.g., sample NOK10d). However, the apparent age obtained for phengite from group 3 in sample NOK10a is very similar to the age obtained for the phengite population in sample NOK10d (Figures $3 \mathrm{~b}$ and 4). If the isotopic equilibrium by intergranular and intragranular diffusion had been efficient, a younger age should have been obtained for the phengite population related to plagioclase breakdown in sample NOK10a than in sample NOK10d. One possible explanation for the limitation of an isotopic equilibrium via diffusion processes is the extremely high $\mathrm{Sr}$ content in the phengite (around $1000 \mathrm{ppm}$ on average). Indeed, as mentioned by Jenkin et al. [1995], a higher Sr content requires a longer amount of time to restore the isotopic equilibrium via volume diffusion, which is highly dependent on temperature. In the present study, the phengite is theoretically within a favorable temperature range for $\mathrm{Sr}$ exchanges by volume diffusion, i.e., $500-600^{\circ} \mathrm{C}$ [e.g., Inger et al., 1996; Villa, 1998]. The volume diffusion of $\mathrm{Sr}$ in epidote is estimated to be effective above $700^{\circ} \mathrm{C}$ [Nagasaki and Enami, 1998], which is within the range of temperatures recorded in samples NOK10a and NOK10b for both the eclogite- and amphibolitefacies metamorphisms. Despite these favorable high thermal conditions, the phengites from different microdomains did not reach an isotopic equilibrium. This suggests that the exchanges are limited to a scale of a few hundred microns, as previously shown by the behavior of trace elements [Schneider et al., 2007].

\subsubsection{Fluid-Controlled Isotopic Equilibrium in Phengite}

[36] In sample NOK10a, the phengite fractions from group 2 do not display the effects of isotopic disequilibrium related to a limited element mobility 
during eclogitization. These phengite fractions are belived to contain the greatest amount of phengite grains from the quartz lenses. The crystallization process of these phengites strongly contrasts with those described for phengites from the NOK10d sample and the phengites from groups 1 and 3 from sample NO10a. The phengites from group 2 did not crystallize after the mineralogical reactions operated between the reacting minerals from a specific microdomain. Their formation involves a crystallization from elements carried and homogenized by fluid. These elements were products in excess released during eclogitization reactions which operated in different microdomains. The fluid phase drained therefore, $\mathrm{Sr}$ with various isotopic compositions (at a hand-sample scale). As a consequence, all of the phengite grains crystallized from the fluid will have a similar ${ }^{87} \mathrm{Sr} /{ }^{86} \mathrm{Sr}$ ratio and will be in isotopic equilibrium (at a hand-sample scale). This process successfully explains why the isotopic disequilibrium observed in phengite from quartz lenses is lower (the apparent age is closer to $\sim 425 \mathrm{Ma}$ ) than in those reported for other phengite groups crystallized in situ. The apparent age of $\sim 457 \mathrm{Ma}$ obtained for these phengite fractions (Figure $3 \mathrm{~b}$ ) is still slightly older than, though within error of, the age of $\sim 425 \mathrm{Ma}$ expected in the case of total equilibrium. This discrepancy should be explained by the fact that these phengite fractions probably contain a minor quantity of phengite grains from other areas, which tends to increase the slope of the isochron and thus, to produce an older age.

\subsubsection{Conclusions for the $\mathrm{Rb} / \mathrm{Sr}$ Radiochronometer Behavior}

[37] The textural and chemical characterization of several of the phengite fractions separated from a single sample allows us to interpret the $\mathrm{Rb} / \mathrm{Sr}$ results as a function of the crystallization mode of the eclogite-facies phengite and to propose a model for the behavior of the $\mathrm{Rb} / \mathrm{Sr}$ chronometer during a HP metamorphism (Figure 10). This model proposes that the eclogite-facies minerals inherit their ${ }^{87} \mathrm{Sr} /{ }^{86} \mathrm{Sr}$ isotopic ratio from their granulite-facies mineral precursors. The calculated apparent $\mathrm{Rb} / \mathrm{Sr}$ ages have no geological significance and more likely result from a strong isotopic disequilibrium registered at the time when the new eclogite-facies minerals crystallized, despite active deformation and fluid circulation. This disequilibrium was not completely erased by the diffusion processes (either intracrystalline or intergranular) due to the very high $\mathrm{Sr}$ content in the studied phengite. The very quick nucleation of the eclogite-facies minerals, resulting from the impregnation of the dry metastable granulite by hydrous fluid in the eclogite-facies conditions [Austrheim, 1990; Bjørnerud et al., 2002; Raimbourg et al., 2007], appears to be one of the main satisfactory explanations for this phenomenon. In addition, as suggested by Zack et al. [2002], the granoblastic texture of the former granulite is another factor that partly controls the segregation of the equilibrium microdomains. It suggests that the chemical and isotopic composition of the eclogite-facies minerals is locally controlled by the composition of the microdomains in which they crystallize. In the present study, neither fluid circulation nor deformation can efficiently homogenize the composition of a mineral species at a hand-sample scale. Only the mineral phases crystallized from elements that have been delocalized by the fluid and precipitated in protected areas of the sample, such as phengite from the quartz lenses, are close to the isotopic equilibrium (as shown by their apparent $\mathrm{Rb} / \mathrm{Sr}$ age close to the $\sim 425 \mathrm{Ma}$ ). Their crystallization mode favors an isotopic equilibrium due to the redistribution process of elements active in a closed system. This model is consistent with the fact that the only $\mathrm{Rb} / \mathrm{Sr}$ ages considered as accurate for the HP event in the Bergen Arcs were obtained on pegmatites derived from the partial melting of the granulites [Kühn et al., 2002], and on quartz veins crystallized from the leaching and precipitation of elements in excess [Glodny et al., 2008]. In both cases, the crystallization mode implies the global rehomogenization of the isotopic ratio of the system and, therefore, allows an isotopic equilibrium to be reached between the different mineral species. Concerning the $\mathrm{Rb} / \mathrm{Sr}$ system behavior, deformation and fluid circulation, as well as the recrystallization process, do not always guarantee the isotopic equilibrium of the system (at a handsample scale) unless they are associated with a complete redistribution of the elements within the system.

[38] This model is relatively similar to those previously proposed in order to explain a $\mathrm{Sm} / \mathrm{Nd}$ or oxygen isotopic disequilibria [e.g., Mørk and Mearns, 1986; Zheng et al., 2002]. Nonetheless, this is the first study that relates such behavior for the $\mathrm{Rb} / \mathrm{Sr}$ system, and in particular for a geological environment, where deformation and fluid circula- 
tion were active during the recrystallization processes. Available data for $\mathrm{Sr}$ behavior in trioctaedric mica indicate that volume diffusion can be activated at temperatures significantly lower (300 to $400^{\circ} \mathrm{C}$ ) than those commonly retained for $\mathrm{Nd}$ in garnet and pyroxene [e.g., Van Orman et al., 2002; Tirone et al., 2005]. Accordingly, the initial isotopic disequilibrium recorded by phengite at the time of its crystallization should be erased by post crystallization diffusion processes. As previously mentioned, such disequilibrium has been preserved within phengite populations which have recrystallized in situ, although they have been maintained at a metamorphic temperature favorable to volume diffusion for almost $15 \mathrm{Ma}$. This is tentatively related to the high $\mathrm{Sr}$ content which is relatively unusual for phengite [e.g., Thöni and Jagoutz, 1992; Amato et al., 1999; Glodny et al., 2003; Di Vincenzo et al., 2006].

\subsection{Ar/Ar System: Excess Argon and Compositional Effects}

[39] The closure temperature for argon diffusion in dioctaedric mica is estimated at around $400-450^{\circ} \mathrm{C}$ on the basis of experimental measurements and field observations [e.g., Robbins, 1972; Hames and Bowring, 1994]. This temperature may be slightly higher for phengite because the substitution of $\mathrm{Fe}$ and $\mathrm{Mg}$ by $\mathrm{Al}$ involves the diminution of the ionic porosity [e.g., Dahl, 1996]. Therefore, given the metamorphic evolution of the Lindås Nappe eclogites, the Ar/Ar ages should have been younger than c. $410 \mathrm{Ma}$, which is the age that has been estimated for the amphibolite-facies metamorphism. However, all of the ages obtained for both samples are intermediate between the ages of the granulite-facies and eclogite-facies metamorphisms (Tables 5 and 6 and Figures 5 and 6), same results were obtained by Boundy et al. [1997a]. Furthermore, the amphibole in sample NOK10d, which crystallized later during the amphibolite-facies event, yields apparent ages older than $\sim 410 \mathrm{Ma}$. This is interpreted as reflecting a variable excess of radiogenic argon in the crystalline lattice of the analyzed minerals. An excess of argon is often discussed in terms of the solubility of argon in the different phases of the system [e.g., Kelley, 2002]. The quantity of excess argon can be roughly estimated by calculating the difference between the apparent age calculated and the true age ( $\sim 25 \mathrm{Ma}$ for phengite). For a given mineral species, the greater the difference, the more important the excess argon becomes. Excess argon is slightly more important in the Phengite-rich sample (NOK10d) than in the Phengite-poor sample (NOK10a), with older apparent ages in the NOK10d sample ( 400-470 Ma in NOK10a and $\sim 450-520$ in NOK10d), whereas the K content in phengite is similar for both samples (0.60.8 a.p.u.f) [Schneider et al., 2007].

[40] During the eclogite-facies metamorphism, the radiogenic argon was preferentially located in the crystalline network of the K-rich granulite-facies minerals (antiperthites in plagioclases), and is released in the rock during their breakdown. Thus, radiogenic argon was certainly transferred into the fluid phase as the argon solubility is significantly higher in the hydrous fluids than in the silicates [e.g., Watson and Cherniak, 2003]. The fluid phase may have acted as a vector to evacuate the excess argon from the system. But, as mentioned above, the fluid circulated in a closed system after its introduction into the rock. Consequently, the excess argon which concentrated in the fluid phase will not be removed from the system but only delocalized. Previous studies [e.g., Kühn, 2002] have demonstrated that the fluid dried up in the course of the crystallization reactions and that its salinity increased. Studies devoted to the solubility of argon in fluids [e.g., Crovetto et al., 1982; Smith and Kennedy, 1983] have demonstrated that argon solubility simultaneously decreases with a decrease in temperature and an increase in the salt content of the fluid. Therefore, in the present study, the fluid will rapidly be saturated in argon. The excess argon could then be incorporated into the different mineralogical species as a function of their argon solubility. For the assemblages described here, the phase with the higher solubility for argon is phengite, followed by quartz and amphibole [Sherlock and Kelley, 2002].

[41] Our results show that the quantity of radiogenic argon in excess is higher in the Phengite-rich sample $\left(\mathrm{K}_{2} \mathrm{O}=1.94 \%\right)$ than in the Phengite-poor sample $\left(\mathrm{K}_{2} \mathrm{O}=0.61 \%\right)$ [Schneider et al., 2007]. This suggests that a correlation exists between the quantity of excess argon and the $\mathrm{K}$ content of the samples, which is in agreement with previous studies [e.g., Kelley, 2002, and references therein]. The variable concentration of excess argon recorded for the various phengite populations analyzed is related to the local variation, at a sample scale, of the quantity of excess argon available in the fluid at the time of their crystallization as well as to the heterogeneous chemical composition of the 
granulite-facies precursors. The presence of excess argon in the rocks can be supported by several factors: (1) the thermal conditions associated with the eclogite-facies metamorphism (HP-LT), often unfavorable to argon diffusion; (2) the very fast exhumation of the eclogites; (3) the lack of penetrative deformation; (4) the absence of an intense fluid circulation; (5) the low porosity of the system at HP conditions, which limits the efficiency of argon diffusion [e.g., Monié, 1985].

[42] In the eclogites studied here, the results show that excess argon was not evacuated from either the phengite or the amphibole, despite the fact that a temperature of up to $650^{\circ} \mathrm{C}$ was maintained for at least $15 \mathrm{Ma}$ after the phengite crystallization [e.g., Glodny et al., 2008]. This again suggests that the limiting factor for the evacuation of radiogenic argon (produced between 930 and $425 \mathrm{Ma}$ ) is the circulation mode of the fluid during the Caledonian metamorphism. Indeed, it has been demonstrated that after its introduction into the system, the fluid evolved in a closed system and its composition changed as the eclogite- and amphibolite-facies reactions progressed [e.g., Kühn, 2002]. Such behavior leads to a decrease in the solubility of argon in the fluid with a higher concentration of excess argon in phengite than in amphibole.

\subsection{Sm/Nd System: Precursor Age Preservation}

[43] The garnet fractions analyzed for both samples mostly contain inherited garnets from the granulitefacies paragenesis, with only thin rims equilibrated in the eclogite facies. The peak temperature achieved during the eclogite-facies metamorphism is close to the closure temperature for the $\mathrm{Nd}$ diffusion in garnet $\left(\sim 750^{\circ} \mathrm{C}\right)$ [Ganguly et al., 1998; Van Orman et al., 2002]. Thus, this feature greatly limits the possibility of isotope equilibration by volume diffusion, which should be expected for the $\mathrm{Sm} / \mathrm{Nd}$ system in garnet during the HP event. Yet, fluid circulation and deformation are often invoked as catalysts for isotope exchanges, even at a low temperature. The $\mathrm{Sm} /$ $\mathrm{Nd}$ ages obtained for both samples are very close to $\sim 930 \mathrm{Ma}$, the age of the granulite-facies metamorphism (Figure 7). These results suggest that garnet inherited from the granulite paragenesis preserved its isotopic characteristics during the eclogitefacies metamorphism. Therefore, it can be stated that even in the presence of an aqueous fluid phase and active ductile deformation, in the lack of total recrystallization, minerals such as garnet will not reach a new isotopic equilibrium, despite a new high grade metamorphic event.

\section{General Conclusion and Implications}

[44] This study allows several conclusions to be drawn concerning the parameters controlling the isotopic equilibrium of the $\mathrm{Rb} / \mathrm{Sr}, \mathrm{Ar} / \mathrm{Ar}$ and $\mathrm{Sm} /$ $\mathrm{Nd}$ radiochronometers during a HP metamorphic event associated with fluid circulation and penetrative ductile deformation:

[45] 1. Inherited minerals with high diffusion temperature for an isotopic system, such as $\mathrm{Nd}$ in garnet, preserved their isotopic record acquired at the time of their crystallization.

[46] 2. Fluid circulation and ductile deformation have no or very limited effects on the reset of an isotopic system if none of the recrystallization processes is effective.

[47] 3. Neocrystallization will induce isotope equilibrium but the scale of equilibrium will be greatly dependent on the crystallization mode.

[48] 4. When neoformed minerals (e.g., phengite) crystallized "on site" following pressure/dissolution processes involving breakdown of a single mineral phase (e.g., plagioclase), or pseudomorphic-like replacement of a mineral (e.g., garnet), they will most likely inherit the isotopic characteristics of their precursor minerals. This will result in a global disequilibrium at a hand-sample scale and will produce meaningless geochronological results.

[49] 5. Neoformed minerals, which precipitated directly from a fluid phase, are prone to be at isotopic equilibrium at a hand-sample scale because they crystallized from a parental fluid with a homogeneous isotopic composition.

[50] 6. A crystallization process that implies the leaching, transport, and then precipitation of elements appears to be the most effective process in order to guarantee isotopic equilibrium during a HP metamorphic event.

[51] 7. For the Ar/Ar system, if a fluid circulates in a closed system at the time of the recrystallization processes, part of the radiogenic argon previously accumulated in the system will not be removed and this will lead to ages without geological meaning due to the trapping of excess of argon by neoformed minerals.

[52] Several authors have warned geochronologists about the occurrence of excess argon despite the 
apparent good quality and coherence of the results [e.g., Li et al., 1994; Boundy et al., 1997a; Sherlock and Arnaud, 1999]. In the literature, the $\mathrm{Ar} / \mathrm{Ar}$ and $\mathrm{Rb} / \mathrm{Sr}$ methods have often been coupled in order to confirm the coherence of the results and especially to detect the presence of excess argon in micas. In the present study, the results obtained for phengite show that both $\mathrm{Rb} / \mathrm{Sr}$ and $\mathrm{Ar} / \mathrm{Ar}$ chronometers are in isotopic disequilibrium, despite the fact that the temperature reached during the metamorphic evolution was much higher than the closure temperatures for both systems.

\section{Acknowledgments}

[53] This work has benefited from financial support by the French Ministry of Research (MENRT grant). We greatly thank Pierre Brunet, from the Paul Sabatier University (Toulouse, France), for his inestimable help during $\mathrm{Sr}$ isotopes analyses. We gratefully acknowledge the assistance of Beatrice Galland in the "Isotope Geochemistry Laboratory" from the Géosciences Montpellier Group and the great help of Philippe Dieudonné from the "Groupe de Dynamique des Phases Condensées" (Univ. Montpellier) during X-ray diffraction analyses. We thank Brad Hacker, Bernard Bingen, and an anonymous reviewer for their constructive reviews and Martin Engi for its valuable suggestions of an early version of the manuscript.

\section{References}

Amato, J. M., C. M. Johnson, L. P. Baumgartner, and B. L. Beard (1999), Rapid exhumation of the Zermatt-Saas ophiolite deduced from high-precision $\mathrm{Sm}-\mathrm{Nd}$ and $\mathrm{Rb}-\mathrm{Sr}$ geochronology, Earth Planet. Sci. Lett., 171, 425-438, doi:10.1016/ S0012-821X(99)00161-2.

Arnaud, N. O., and S. Kelley (1995), Evidence for excess argon during high pressure metamorphism in the Dora maira massif (Western Alps, Italy), using an ultra-violet laser ablation microprobe ${ }^{40} \mathrm{Ar}^{39} \mathrm{Ar}$ technique, Contrib. Mineral. Petrol., 121, 1-11, doi:10.1007/s004100050086.

Austrheim, H. (1987), Eclogitization of lower crustal granulites by fluid migration through shear-zones, Earth Planet. Sci. Lett., 81, 221-232, doi:10.1016/0012-821X(87)90158-0.

Austrheim, H. (1990), The granulite-eclogite facies transition: A comparison of experimental work and a natural occurrence in the Bergen Arcs, western Norway, Lithos, 25, 163-169, doi:10.1016/0024-4937(90)90012-P.

Austrheim, H., and W. L. Griffin (1985), Shear deformation and eclogite formation within granulite-facies anorthosites of the Bergen arcs, western Norway, Chem. Geol., 50, 267281, doi:10.1016/0009-2541(85)90124-X.

Bingen, B., W. J. Davis, and H. Austrheim (2001), Zircon $\mathrm{U} / \mathrm{Pb}$ geochronology in the Bergen arcs eclogites and their Proterozoic protoliths, and implication for the pre-Scandian evolution of the Caledonides in western Norway, Geol. Soc. Am. Bull., 113, 640-649, doi:10.1130/0016-7606 (2001)113<0640:ZUPGIT>2.0.CO;2.

Bingen, B., A. Austrheim, M. J. Whitehouse, and W. J. Davis (2004), Trace element signature and U-Pb geochronology of eclogite-facies zircon, Bergen Arcs, Caledonides of W Nor- way, Contrib. Mineral. Petrol., 147, 671-683, doi:10.1007/ s00410-004-0585-z.

Bjørnerud, M. G., H. Austrheim, and M. G. Lund (2002), Processes leading eclogitization (densification) of subducted and tectonically buried crust, J. Geophys. Res., 107(B10), 2252, doi:10.1029/2001JB000527.

Boundy, T. M., D. M. Fountain, and H. Austrheim (1992), Structural development and petrofabrics of eclogite facies shear zones, Bergen Arcs, western Norway: Implications for deep crustal deformational processes, J. Metamorph. Geol., 10, 127-146, doi:10.1111/j.1525-1314.1992. tb00075.x.

Boundy, T. M., E. J. Essene, C. M. Hall, H. Austrheim, and A. N. Halliday (1996), Rapid exhumation of lower crust during continent-continent collision and late extension: Evidence from ${ }^{40} \mathrm{Ar} /{ }^{39} \mathrm{Ar}$ incremental heating of hornblendes and muscovites, Caledonian orogen, western Norway, Geol. Soc. Am. Bull., 108, 1425-1437, doi:10.1130/0016-7606(1996)108 $<1425$ :REOLCD $>2.3$. CO;2.

Boundy, T. M., C. M. Hall, G. Li, E. J. Essene, and A. N. Halliday (1997a), Fine-scale isotopic heterogeneities and fluids in the deep crust: A 40Ar/39Ar laser ablation and TEM study of muscovites from granulite-eclogite transition zone, Earth Planet. Sci. Lett., 148, 223-242, doi:10.1016/ S0012-821X(97)00036-8.

Boundy, T. M., K. Mezger, and E. J. Essene (1997b), Temporal and tectonic evolution of the granulite-eclogite association of the Bergen Arcs, western Norway, Lithos, 39, 159-178, doi:10.1016/S0024-4937(96)00026-6.

Boundy, T. M., C. L. Donohue, E. J. Essene, K. Mezger, and H. Austrheim (2002), Discovery of eclogite facies carbonate rocks from the Lindås Nappe, Caledonides, Western Norway, J. Metamorph. Geol., 20, 649-667, doi:10.1046/j.15251314.2002.00396.x.

Burton, K. W., M. J. Kohn, A. S. Cohen, and R. K. O'Nion (1995), The relative diffusion of $\mathrm{Pb}, \mathrm{Nd}, \mathrm{Sr}$ and $\mathrm{O}$ in garnet, Earth Planet. Sci. Lett., 133, 199-211, doi:10.1016/0012821X(95)00067-M.

Cliff, R. A., A. C. Barnicoat, and S. Inger (1998), Early Tertiary eclogite facies metamorphism in the Monviso Ophiolite, J. Metamorph. Geol., 16, 447-455, doi:10.1111/j.1525-1314.1998.00147.x.

Cohen, A. S., R. K. O'Nions, R. Siegenthaler, and W. L. Griffin (1988), Chronology of pressure temperature history recorded by a granulite terrain, Contrib. Mineral. Petrol., 98, 303-311, doi:10.1007/BF00375181.

Crovetto, R., R. Fernandez-Prini, and M. L. Japas (1982), Solubilities of inert gases and methane in $\mathrm{H} 2 \mathrm{O}$ and $\mathrm{D} 2 \mathrm{O}$ in the temperature range of 300 to $600 \mathrm{~K}, \mathrm{~J}$. Chem. Phys., 76, 1077-1086, doi:10.1063/1.443074.

Dahl, P. S. (1996), The crystal-chemical basis for Ar retention in micas: Inferences from interlayer partitioning and implications for geochronology, Contrib. Mineral. Petrol., 123, 22-39, doi:10.1007/s004100050141.

Dallmeyer, R. D., P. G. Andréasson, and O. Svenningsen (1991), Initial tectonothermal evolution with the Scandinavian Caledonide accretionnary prism: Constraints from ${ }^{40} \mathrm{Ar} /{ }^{39} \mathrm{Ar}$ mineral ages within the Seve Nappe Complex, Sarek Mountains, Sweden, J. Metamorph. Geol., 9, $203-$ 208, doi:10.1111/j.1525-1314.1991.tb00515.x.

De Jong, K. (2003), Very fast exhumation of high-pressure metamorphic rocks with excess ${ }^{40} \mathrm{Ar}$ and inherited ${ }^{87} \mathrm{Sr}, \mathrm{Be}-$ tic Corrdilleras, southern Spain, Lithos, 70, 91-110, doi:10.1016/S0024-4937(03)00094-X.

De Jong, K., G. Féraud, G. Ruffet, M. Amouric, and J. R. Wijbrans (2001), Excess argon incorporation in phengite of 
the Mulhacén Complex: Submicroscopic illitization and fluid ingress during late Miocene extension in the Betic Zone, south-eastern Spain, Chem. Geol., 178, 159-195, doi:10.1016/S0009-2541(00)00411-3.

De Wolf, C. P., C. J. Zeissler, A. N. Halliday, K. Mezger, and E. J. Essene (1996), The role of inclusions in $\mathrm{U} / \mathrm{Pb}$ and $\mathrm{Sm} /$ $\mathrm{Nd}$ garnet geochronology: Stepwise dissolution experiments and trace uranium mapping by fisson track analysis, Geochim. Cosmochim. Acta, 60, 121-134, doi:10.1016/00167037(95)00367-3.

Di Vincenzo, G., S. Tonarini, B. Lombardo, D. Castelli, and L. Ottolini (2006), Comparison of ${ }^{40} \mathrm{Ar}^{39} \mathrm{Ar}$ and $\mathrm{Rb}-\mathrm{Sr}$ data on phengites from the UHP Brossasco-Isasca unit (Dora Maira Massi, Italy): Implications for dating white mica, J. Petrol., 47, 1439-1465, doi:10.1093/petrology/ eg1018.

Dodson, M. H. (1973), Closure temperature in cooling geochronological and petrological systemsContrib. Mineral. Petrol., 40, 259-274, doi:10.1007/BF00373790.

Farquhar, J., T. Chacko, and D. J. Ellis (1996), Preservation of oxygen isotope compositions in granulites from Northwestern Canada and Enberby Land, Antarctica: Implication for high-temperature isotope thermometry, Contrib. Mineral. Petrol., 125, 213-224, doi:10.1007/s004100050217.

Fleck, R. J., J. F. Sutter, and D. H. Elliot (1977), Interpretation of discordant 40Ar/39Ar age-spectra of Mesozoic tholeiites from Antarctica, Geochim. Cosmochim. Acta, 41, 15-32, doi:10.1016/0016-7037(77)90184-3.

Foland, K. A. (1979), Limited mobility of argon in a metamorphic terrain, Geochim. Cosmochim. Acta, 43, 793-801, doi:10.1016/0016-7037(79)90219-9.

Ganguly, J., M. Tirone, and R. L. Hervig (1998), Diffusion kinetics of Samarium and Neodynium in garnet, and a method for determining cooling rates of rocks, Sciences N. Y., $281,805-807$.

Giletti, B. J., and R. A. Yund (1984), Oxygen diffusion in quartz, J. Geophys. Res., 89, 4039-4046, doi:10.1029/ JB089iB06p04039.

Glodny, J., H. Austrheim, J. F. Molina, A. I. Rusin, and D. Seward (2003), $\mathrm{Rb} / \mathrm{Sr}$ record of fluid-rock interaction in eclogites: The Marun-Keu complex, Polar Urals, Russia, Geochim. Cosmochim. Acta, 67, 4353-4371, doi:10.1016/S0016-7037(03)00370-3.

Glodny, J., A. Kuhn, and H. Austrheim (2008), Geochronology of fluid-induced eclogite and amphibolite facies metamorphic reactions in a subduction-collision system, Bergen Arcs, Norway, Contrib. Mineral. Petrol., 156, 27-48, doi:10.1007/s00410-007-0272-y.

Griffin, W. L., and H. Brueckner (1985), REE, Rb-Sr and SmNd studies of Norwegian eclogites, Chem. Geol., 52, 249271

Hames, W. E., and S. A. Bowring (1994), An empirical evaluation of the argon diffusion geometry in muscovite, Earth Planet. Sci. Lett., 124, 161-167, doi:10.1016/0012-821X (94)00079-4.

Inger, S., W. Ramsbotham, R. A. Cliff, and D. C. Rex (1996), Metamorphic evolution of the Sesia-Lanzo Zone, Western Alps: Time constraints from multi-system geochronology, Contrib. Mineral. Petrol., 126, 152-168, doi:10.1007/ s004100050241.

Jagoutz, E. (1995), Isotopic constraints on garnet equilibration, Terra Nova Abs., 7, 339.

Jamtveit, B., K. Bucher-Nurminen, and H. Austrheim (1990), Fluid controlled eclogitization of granulites in deep crustal shear zones, Bergen arcs, Western Norway, Contrib. Mineral. Petrol., 104, 184-193, doi:10.1007/BF00306442.
Jenkin, G. R. T. (1997), Do cooling paths derived from mica $\mathrm{Rb}-\mathrm{Sr}$ data reflect true cooling paths?, Geology, 25, $907-$ 910, doi:10.1130/0091-7613(1997)025<0907:DCPDFM> 2.3. $\mathrm{CO} ; 2$

Jenkin, G. R. T., G. Rogers, A. E. Fallick, and C. M. Farrow (1995), Rb-Sr closure temperature in bi-mineralic rocks: A mode effect and test for different diffusion models, Chem. Geol., 122, 227-240, doi:10.1016/0009-2541(95)00013-C.

Kelley, S. (2002), Excess argon in K-Ar and Ar-Ar geochronology, Chem. Geol., 188, 1-22, doi:10.1016/S00092541(02)00064-5.

Kretz, R. (1983), Symbols for rock-forming minerals, Am. Mineral., 68, 277-279.

Kühn, A. (2002), The influence of fluid on the granulite to eclogite and amphibole facies transition: A study in the anorthositic rocks from the Lindas Nappe, Bergen arcs, West Norway, M.S. thesis, Fac. of Math. and Nat. Sci., Univ. of Oslo, Norway.

Kühn, A., J. Glodny, K. Iden, and H. Austrheim (2000), Retention of Precambrian $\mathrm{Rb} / \mathrm{Sr}$ phlogopite ages through Caledonian eclogites facies metamorphism, Bergen Arc Complex, W-Norway, Lithos, 51, 305-330, doi:10.1016/ S0024-4937(99)00067-5.

Kühn, A., J. Glodny, H. Austrheim, and A. Råheim (2002), The Caledonian tectono-metamorphic evolution of the Lindås Nappe: Constraints from U-Pb, Sm-Nd and Rb-Sr ages of granitoid dykes, Nor. Geol. Tidsskr., 82, 45-57.

Li, S., S. Wang, Y. Chen, D. Liu, H. Zhou, and Z. Zhang (1994), Excess argon in phengite from eclogite: Evidence from dating of eclogite minerals by $\mathrm{Sm}-\mathrm{Nd}, \mathrm{Rb}-\mathrm{Sr}$ and ${ }^{40} \mathrm{Ar} /{ }^{39} \mathrm{Ar}$ methods, Chem. Geol., 112, 343-350, doi:10.1016/0009-2541(94)90033-7.

Li, S., E. Jagoutz, Y. Chen, and Q. Li (2000), Sm-Nd and RbSr isotopic chronology and cooling history of ultrahigh pressure metamorphic rocks and their country rocks at Shuanghe in the Dabie Mountains, central China, Geochim. Cosmochim. Acta, 64, 1077-1093, doi:10.1016/S0016-7037(99) 00319-1.

Luais, B., P. Télouk, and F. Albarède (1997), Precise and accurate measurements by plasma-source mass spectrometry, Geochim. Cosmochim. Acta, 61, 4847-4854, doi:10.1016/ S0016-7037(97)00293-7.

Ludwig, K. R. (2001), User manual for Isoplot/Ex version 2.49, a geochronological toolkit for Microsoft Excel, Spec. Publ. 1a, Berkeley Geochronol. Cent., Berkley, Calif.

Maurel, O., P. Monié, J. P. Respaut, A. F. Leyreloup, and H. Maluski (2003), Pre-metamorphic ${ }^{40} \mathrm{Ar} /{ }^{39} \mathrm{Ar}$ and $\mathrm{U}-\mathrm{Pb}$ ages in HP metagranitoids from the Hercynian belt (France), Chem. Geol., 193, 195-214, doi:10.1016/S0009-2541(02) 00351-0.

McDougall, I., and T. M. Harrison (Eds.) (1988), Geochronology and Thermochronology By the ${ }^{40} \mathrm{Ar} /{ }^{39} \mathrm{Ar}$ Method, Oxford Univ. Press, Oxford, U. K.

Miller, C., and M. Thöni (1997), Eo-Alpine eclogitization of Permian MORB-type gabbros in the Koralpe (Eastern Alps, Austria): New geochronological, geochimical and petrological data, Chem. Geol., 137, 283-310, doi:10.1016/S00092541(96)00165-9.

Monié, P. (1985), La méthode ${ }^{39} \mathrm{Ar}-{ }^{40} \mathrm{Ar}$ appliquée au métamorphisme alpin dans le massif du Mont-Rose (Alpes Occidentales). Chronologie détaillée depuis $110 \mathrm{Ma}$, Eclogae Geol. Helv., 78, 487-516.

Mørk, M. B. E., and E. W. Mearns (1986), Sm-Nd isotopic systematics of a gabbro-eclogite transition, Lithos, 19, 255 267, doi:10.1016/0024-4937(86)90026-5. 
Nagasaki, A., and M. Enami (1998), Sr-bearing zoisite and epidote in ultra-high pressure (UHP) metamorphic rocks from the $\mathrm{Su}-\mathrm{Lu}$ province, eastern China: An important $\mathrm{Sr}$ reservoir under UHP conditions, Am. Mineral., 83, 240247.

Paquette, J. L., C. Chopin, and J. J. Peucat (1989), U-Pb zircons, $\mathrm{Rb}-\mathrm{Sr}$ and $\mathrm{Sm}-\mathrm{Nd}$ geochronology of high-to very-high-pressure meta-acidic rocks from the Western Alps, Contrib. Mineral. Petrol., 101, 280-289, doi:10.1007/BF00375313.

Raimbourg, H., B. Goffé, and L. Jolivet (2007), Garnet reequilibration and growth in the eclogite facies and geodynamical evolution near peak metamorphic conditions, Contrib. Mineral. Petrol., 153, 1-28, doi:10.1007/s00410-006-0130-3.

Robbins, G. A. (1972), Radiogenic argon diffusion in muscovite under hydrothermal conditions, M.S. thesis, 189 pp., Brown Univ., Providence, R. I.

Rockow, K. M., L. A. Haskin, B. L. Jolliff, and D. M. Fountain (1997), Constraints on element mobility associated with the conversion of granulite to eclogite along fractures in an anorthositic complex on Holsnoy, Norway, J. Metamorph. Geol., 15, 401-418, doi:10.1111/j.1525-1314.1997.00028.x.

Samson, S. D., and E. C. Alexander (1987), Calibration of the interlaboratory 40Ar-39Ar dating standard, MMhb-1, Chem. Geol., 66, 27-34.

Santos Zalduegui, J. F., U. Schärer, and G. J. I. Ibarguchi (1995), Isotope constraint on the age an origin of magmatism and metamorphism in the Malpica-Tuy allochthon, Galicia, NW Spain, Chem. Geol., 121, 91-103, doi:10.1016/00092541(94)00123-P

Scherer, E. E., K. L. Cameron, and J. Blichert-Toft (2000), LuHf garnet geochronology: Closure temperature relative to the $\mathrm{Sm}-\mathrm{Nd}$ system and the effects of trace mineral inclusions, Geochim. Cosmochim. Acta, 64, 3413-3432, doi:10.1016/ S0016-7037(00)00440-3.

Schmädicke, E., K. Mezger, M. A. Cosca, and M. Okrusch (1995), Variscan Sm-Nd and Ar-Ar ages of eclogite facies rocks from the Erzgebirge, Bohemian Massif, J. Metamorph. Geol., 13, 537-552, doi:10.1111/j.1525-1314.1995. tb00241.x.

Schneider, J., D. Bosch, P. Monié, S. Guillot, A. Garcia-Casco, J. M. Lardeaux, R. L. Torres-Roldan, and G. Millan Trujillo (2004), Origin and evolution of the Escambray Massif (Central Cuba): An example of HP/LT rocks exhumed during intraoceanic subduction, J. Metamorph. Geol., 22, 227247, doi:10.1111/j.1525-1314.2004.00510.x.

Schneider, J., D. Bosch, P. Monié, and O. Bruguier (2007), Micro-scale element migration during eclogitization in the Bergen arcs (Norway): A case study on the role of fluids and deformation, Lithos, 96, 325-352, doi:10.1016/ j.lithos.2006.10.001.

Sherlock, S. C., and N. O. Arnaud (1999), Flat plateau and impossible isochrons: Apparent ${ }^{40} \mathrm{Ar}-{ }^{39} \mathrm{Ar}$ geochronology in a high-pressure terrain, Geochim. Cosmochim. Acta, 63(18), 2835-2838, doi:10.1016/S0016-7037(99)00116-7.

Sherlock, S., and S. Kelley (2002), Excess argon evolution in HP-LT rocks: A UVLAMP study of phengite and K-free minerals, NW Turkey, Chem. Geol., 182, 619-636, doi:10.1016/S0009-2541(01)00345-X.
Smith, S. P., and B. M. Kennedy (1983), The solubility of noble gases in water and in $\mathrm{NaCl}$ brine, Geochim. Cosmochim. Acta, 47, 503-515, doi:10.1016/0016-7037(83) 90273-9.

Sun, S. S., and W. F. McDonough (1989), Chemical and isotopic systematics of oceanic basalts; implications for mantle composition and processes, Geol. Soc. Spec. Publ., 42, $313-$ 345.

Thöni, M. (2003), Sm-Nd isotope systematics in garnet from different lithologies (Eastern Alps): Age results, and an evaluation of potential problems for garnet Sm-Nd chronometry, Chem. Geol., 194, 353-379, doi:10.1016/S00092541(02)00419-9.

Thöni, M., and E. Jagoutz (1992), Some new aspect of dating eclogites in orogenic belts: $\mathrm{Sm}-\mathrm{Nd}, \mathrm{Rb}-\mathrm{Sr}$ and $\mathrm{Pb}-\mathrm{Pb}$ isotopic results from the Austroalpine Sauralpe and Koralpe typelocality (Carinthia/Styria, southeastern Austria), Geochim. Cosmochim. Acta, 56, 347-368, doi:10.1016/0016-7037 (92)90138-9.

Tirone, M., J. Ganguly, R. Dohmen, F. Langenhorst, R. Hervig, and H.-W. Becker (2005), Rare earth diffusion kinetics in garnet: Experimental studies and applications, Geochim. Cosmochim. Acta, 69, 2385-2398, doi:10.1016/j.gca.2004. 09.025.

Van Orman, J. A., T. L. Grove, N. Shimizu, and G. D. Layne (2002), Rare earth element diffusion in a natural pyrope single crystal at $2.8 \mathrm{Gpa}$, Contrib. Mineral. Petrol., 142, 416-424

Verschure, R. H., P. A. M. Andriessen, N. A. I. M. Boelrijk, E. H. Hebeda, C. Maijer, H. N. A. Priem, and A. A. T. Verdurmen (1980), On the thermal stability of $\mathrm{Rb}-\mathrm{Sr}$ and $\mathrm{K}-\mathrm{Ar}$ biotite systems: Evidence from coexisting Sveconorwegian (ca 870Ma) and Caledonian (ca 400Maaa) biotites in SW Norway, Contrib. Mineral. Petrol., 74, 245-252, doi:10.1007/BF00371694.

Villa, I. M. (1998), Isotopic closure, Terra Nova, 10, 42-47, doi:10.1046/j.1365-3121.1998.00156.x.

Watson, E. B., and D. J. Cherniak (2003), Lattice diffusion of $\mathrm{Ar}$ in quartz, with constraints on Ar solubility and evidence of nanopores, Geochim. Cosmochim. Acta, 67, 2043-2062, doi:10.1016/S0016-7037(02)01340-6.

Xie, Z., Y.-F. Zheng, B. M. Jahn, M. Ballèvre, J. Chen, P. Gautier, T. Gao, B. Gong, and J. Zhou (2004), Sm-Nd and $\mathrm{Rb}-\mathrm{Sr}$ dating of pyroxene-garnetite from Dabie east-central China: Problem of isotope disequilibrium due to retrograde metamorphism, Chem. Geol., 206, 137-158, doi:10.1016/ j.chemgeo.2004.01.013.

Zack, T., S. F. Foley, and T. Rivers (2002), Equilibrium and disequilibrium trace element partitioning in hydrous eclogites (Trescolmen, Central Alps), J. Petrol., 43, $1947-$ 1974, doi:10.1093/petrology/43.10.1947.

Zheng, Y.-F., Z.-R. Wang, S.-G. Li, and Z.-F. Zhao (2002), Oxygen isotope equilibrium between eclogite minerals and its constraints on mineral Sm-Nd chronometer, Geochim. Cosmochim. Acta, 66, 625-634, doi:10.1016/S00167037(01)00801-8.

Zhou, B., and B. J. Hensen (1995), Inherited Sm/Nd isotope components preserved in monazite inclusions within garnets in leucogneiss from East Antarctica and implications for closure temperatures studies, Chem. Geol., 121, 317-326, doi:10.1016/0009-2541(94)00130-Z. 